\title{
Brokers, clients and elite political networks in Mexico
}

\author{
Tod Van Gunten \\ University of Edinburgh \\ tvangun@ed.ac.uk
}

\begin{abstract}
In closed but competitive political regimes, political leaders face a strategic choice between centralizing and inclusive strategies of elite coalition formation. While studies of political networks in these regimes focus on patron-client systems - a classic centralization strategy I argue that political leaders are likely to pursue mixed strategies that blend patronage with more deferential strategies, including elite brokerage. This paper analyzes the role of patronclient ties and brokerage positions in Mexican cabinet appointments over a period of sixty years (1940-2000), demonstrating that elite brokers were more likely to be included in elite coalitions. Although network theorists have argued that brokers are most important in "factionalized" elites, the results show that brokers were valued elite coalition partners during the period of consolidated one-party rule, but not during the earlier, more contested period of regime formation. The analysis also suggests that patronage became less hierarchical as the regime consolidated, shifting towards a sponsorship system of competing patrons rather than a classic patronage pyramid.
\end{abstract}

Keywords: political networks, brokerage, patron-client relations, state structure, Latin America

Acknowledgements: I thank John Levi Martin, Edo Navot, Joseph Harris, Mark Lutter, Jacob Habinek, Nico Sonntag, Didac Queralt, Avital Livny and Rickhard Sandell for suggestions and comments, Roderic Camp for making the data available, and Luis Martínez for valuable research assistance.

\section{Working paper}


Beneath any process of state formation or transformation lies a trajectory of elite emergence and consolidation. Seen from the micro level, the construction of a political regime reflects the crystallization of a particular political elite, with its characteristic patterns of competition, cooperation, and conflict. This paper opens this black box by analyzing the logic of elite coalition formation, focusing on the choice between centralizing patronage strategies and more deferential strategies incorporating intra-elite brokers. I argue that simple patronage is unlikely to provide a durable basis for elite coalition formation in heterogeneous and competitive elites. Instead, as regimes consolidate, leaders develop mixed strategies of coalition formation that blend patronage and brokerage logics.

Studies of elite transformation and political change draw extensively on theories of patron-client structures (Bearman, 1993; Gould, 1996, 2003; Padgett and Ansell, 1993; McLean, 2011) and political brokerage (Fernandez and Gould, 1994; Gould, 1989; Hillmann, 2008a,b; Stovel and Shaw, 2012). However, patronage and brokerage are usually analyzed separately; existing integrations address only special cases of brokerage. Some accounts (Hillmann, 2008a; Kettering, 1986) conceptualize brokers as vertical intermediaries in hierarchical patron-client relations, often spanning geographical or status divisions between elite and non-elite (or less elite) actors (c.f. Stovel and Shaw, 2012: 149). Others, in particular the classic work of Padgett and Ansell (1993), posit that powerful leaders emerge from unique brokerage positions at the center of patron-client pyramids. Neither fully encompasses the general phenomenon of brokerage in the sense of actors spanning structural holes between individuals, groups or clusters in complex networks (Burt, 1992; Fernandez and Gould, 1994). It is also unclear how to integrate broad theories of political brokerage with Gould's (1989: 532, 536) claim that brokers have greatest relevance in "elites characterized by stable factional structures" and are less relevant "when consensus within the elite increases." Since many elites are not factionalized, this hypothesis appears to greatly constrain the range of contexts in which brokerage is politically salient. This paper analyzes brokerage and patron-client relations as alternative logics of coalition formation, while showing that in a context of coalition formation brokerage can be more salient in a context of stable, consolidated rule than factionalism.

In addition, the literature suffers from an empirical omission with important theoretical ram- 
ifications. Research on elite political networks has focused primarily on patrimonial regimes and emergent democracies, reflecting the selection of European and North American cases as research sites. The developing world is notably absent from this research agenda. This empirical omission is theoretically important: single- and dominant party regimes from China to sub-Saharan Africa feature dynamics of elite competition which differ substantively from other regime types. In particular, these regimes combine elite competition with organizational closure - the channeling of competition within the boundaries of a single party. Because of the importance of informal institutions, these cases provide a rich context to test patronage and brokerage theories of elite political action. Yet while there are many discussions of elite patronage in these regimes (Centeno, 1997; Shih et al., 2012; Willerton, 1992; Levitsky and Way, 2012), few use systematic network data, and none test patronage and brokerage theories simultaneously.

To address these issues, this paper examines elite coalition formation in the Institutional Revolutionary Party (PRI) regime which dominated Mexico for most of the 20th century. I analyze the role of patron-client ties and brokerage empirically by examining the determinants of cabinet appointments over a period of sixty years (1940 to 2000), encompassing the formation and consolidated rule of the dominant party regime. Elite coalition formation strategies are likely to change as regimes form and consolidate. Patronage is an empirically common strategy of elite coalition formation but is unlikely to sustain elite cooperation and deter intra-elite conflicts. Moreover, observed patronage structures in competitive elites fall well short of the ideal-typical model of pyramidal hierarchy, resembling web-like partial hierarchies rather than strict pyramids (Martin, 2009). This sponsorship model implies that there are substantial horizontal brokerage opportunities available in elite networks. Contrary to the claim that brokers are only politically salient in factionalized contexts (Gould, 1989), I propose that recruiting brokers to elite coalitions is a deferential strategy to fill gaps, promote cooperation, and avoid conflict. Taken together, these arguments imply a shift away from top-down strategies of elite patronage and towards more deferential and inclusive strategies, including brokerage appointments.

The analysis relies on a new dataset derived from a compilation of political biographies (Camp, 2011) that records the educational and career histories of senior political elites active during a 
long historical period (1935-2009). The dataset is one of the most complete compendia of elite political biographies for any country (Camp, 2010); this paper is the first to exploit this rich source by leveraging the full career histories. Drawing on longstanding observations among scholars of Mexican political elites, these data permit inferences about network ties based on elites' education and career trajectories. I estimate logistic regression models of the odds of cabinet appointment as a function of patron-client ties, network size and brokerage positions, controlling for indicators of elite experience and training. The analysis shows that brokers had a significantly higher probability of recruitment to elite coalitions during the period of consolidated one-party rule, but had no apparent value as coalition members during the earlier period of regime formation. Moreover, the findings support a "sponsorship" variant of patron-client relations (Martin, 2009) over a strictly hierarchical model and suggest that this comparatively decentralized logic intensified as the regime consolidated.

This analysis has three key implications for studies of regime formation and political networks. First, while there is a long tradition of research on brokerage in economic networks, only a handful of studies have used systematic network data to study political brokerage (Padgett and Ansell, 1993; Fernandez and Gould, 1994; Gould, 1989; Hillmann, 2008a,b), all of which focus on either (proto-) democratic or patrimonial regimes. Thus, these results demonstrate the political salience of brokerage in a substantively new political context, which is both empirically common and an informative setting in which to explore informal elite competition. Conversely, the analysis demonstrates that political network dynamics in these settings are not limited to patron-client relations as often assumed, and shows that the hierarchical logic of patronage attenuated as the regime consolidated. Second, evidence that brokerage was more important in the consolidated regime than during the earlier period of regime formation contradicts the intuitive expectation that brokers are most valuable in unsettled or factionalized contexts (Gould, 1989). Instead, the analysis shows that in a context of elite coalition formation, brokers are strategic allies. Third, these findings represent a twist on the classic work of Padgett and Ansell (1993) on political action and network position, redirecting attention to the decentralizing logic of elite brokerage.

The following section draws on the political networks literature to develop the implications of patron-client and brokerage theories for elite coalition formation. Next, I introduce some key 
features of the Mexican political elite. After presenting the empirical data and methodology, the subsequent section presents the results. The paper concludes by returning to the broader theoretical implications of the analysis.

\section{Elite coalition formation}

Closed but competitive elites ${ }^{1}$ are an informative context in which to explore the role of social networks in elite behavior because so much political action in these regimes involves informal institutions. Regimes dominated by closed elites are empirically common and diverse, including Communist systems such as the Soviet Union and China, "competitive authoritarian" regimes (Levitsky and Way, 2010) including 20th-century Mexico, and dominant party democracies such as India and Japan. In contrast to patrimonial regimes, rulers and their kin do not monopolize political power; rather, there is substantial leadership turnover despite weak or non-existent democratic institutions. As a result of this frequent exchange of power, these political systems are not devoid of political competition: rather, they internalize political competition within organizational boundaries, and thereby into informal and weakly institutionalized processes. Loosely defined factions and informal hierarchies are the primary units of political competition. This makes these political regimes an important testing ground for social network theory, which argues that relational structures are analytically prior to groups and categorical identities.

Despite organizational closure, governing these competitive elites requires forming elite coalitions. Even leaders with near-absolute power must delegate authority in order to execute their political agenda, creating the potential for principal-agent problems. Because closed elites internalize political competition, informal divisions between "left" and "right" wings, reformers and hard-liners and other sources of heterogeneity can undermine cooperation and foment internal conflict. Thus, strategies of elite coalition formation are an important facet of the logic of political action in regimes dominated by informal institutions.

Broadly speaking, political leaders face a strategic choice between top-down centralization and

\footnotetext{
${ }^{1}$ For simplicity, I will refer alternately to "competitive" and "closed" elites rather than the more cumbersome "closed but competitive."
} 
more inclusive, deferential strategies of elite coalition formation. In principle, most leaders in these regimes probably prefer to maximize their capacity for control by centralizing power in their own hands. Elites who are particularly charismatic, able to exercise violence, or politically skilled may succeed. But in competitive elites, attempts to monopolize control frequently backfire, undermining a leader's grip on power and the implementation of their agenda. Subordinate elites can engage in a variety of non-cooperative behaviors, ranging from withholding political effort and redirecting resources towards their own objectives to outright dissent and defection. Marginalizing competitors through top-down centralization risks provoking intra-elite conflict and undermines incentives to cooperate. The alternative is to demonstrate deference and inclusion, seeking to sustain elite cooperation by incorporating and placating members of the broader elite. In contrast to centralization and top-down control, deferential strategies sacrifice some of the prerogatives of leadership, but may achieve gains in elite cooperation.

The balance struck between these coalition formation strategies is likely to change as regimes emerge and consolidate. Many closed elites form following revolution, civil war, or independence struggles; even after armed conflict ends, political regimes (identifiable rules governing elite competition and access to power) often develop slowly. For example, Burton and Higley (1987: 299) argue that elite "settlements" require between several years and a full generation to consolidate. Any regime - democratic or otherwise - is consolidated to the extent that political action (particularly elite behavior) generally abides by some set of identifiable "rules of the game," either formal or informal. ${ }^{2}$ Regime consolidation reduces political uncertainty: as elites come to take behavioral conformity with these rules for granted, they develop relatively stable expectations about the likely behavior of competitors. These expectations shape strategies, including strategies of coalition formation. Although elite expectations are difficult to observe directly, particularly in historical retrospect, one simple empirical indicator of consolidation is behavioral consistency over time: the longer patterns of political competition (such as regularities in leadership turnover) persist, the more elites begin to take them for granted. Conversely, elite conflict over leadership succession (i.e. access to power), is an empirical indicator of the absence of consolidation. Consolidation, in

\footnotetext{
${ }^{2}$ This definition is consistent with that of Burton et al. (1991), generalized to non-democratic regimes. That is, consolidation refers to conformity with the rules of the politcal game, whether or not this game is democratic.
} 
contrast, is a "dog that doesn't bark:" the absence of visible violations of the rules of the political game is the clearest indication that these rules are generally accepted.

\section{$1.1 \quad$ Patron-client networks}

A common strategy of centralizing power is to build elite coalitions of trusted agents. For example, observers of Chinese politics argue that political leaders "built networks of loyal followers to mitigate the fundamental uncertainty in elite politics" (Shih et al., 2012: 169). Such strategies follow a patron-client logic: asymmetric exchanges between a superior who offers valued resources (such as political positions) in exchange for the loyalty and support of a subordinate (Eisenstadt and Roniger, 1984; Martin, 2009; Scott, 1972; Grindle, 2012). Scholars have argued that elite patronage systems are the basis for coalition formation and elite appointments in contexts as varied as China (Shih et al., 2012; Keller, 2016), the Soviet Union (Willerton, 1992), post-colonial African states such as Cote d'Ivoire, Kenya and Senegal (Arriola, 2009; Van de Walle, 2007), and even in more democratic regimes such as Japan (Curtis, 2013). As the next section shows, previous work on the Mexican political elite often invokes similar notions (Centeno, 1997; Grindle, 1977).

The patron-client model suggests a straightforward hypothesis: leaders are more likely to recruit elites to their coalition with whom they share pre-existing direct ties. The model is also consistent with the hypothesis that indirect ties to a leader also provide a promotion advantage, although this may not always be the case. ${ }^{3}$ More generally, network theorists describe patron-client systems as hierarchical, pyramidal structures in which ties are strictly asymmetric, horizontal ties are absent, and clients serve only one patron (Martin, 2009; Montgomery, 2007; Gould, 1996). This pyramidal, top down model has been suggested for regimes such as Putin's Russia (Hale, 2010) and Mexico (Centeno, 1997; Schlefer, 2008: 148). Thus, at the structural level, the strict patronage model implies that elite networks exhibit properties of pyramidal or tree-like hierarchies (Krackhardt, 1994).

Although some authors argue that patron-client pyramids create incentives for elite cooperation (Levitsky and Way, 2012), it is unclear that strict patronage hierarchies provide a durable basis

\footnotetext{
${ }^{3}$ As Martin (2009) notes, in some patron-client systems indirect (two-step) ties imply loyalty, but not in all.
} 
for coalition formation in competitive elites. Patronage systems are potentially unstable for several reasons. First, patronage hierarchies have no obvious mechanism for orchestrating leadership turnover at the top: removing the "patron's patron" at the apex of the pyramid eliminates the unique source of elite solidarity. Each client has an equal claim to succeed the incumbent patron, threatening to provoke leadership conflicts. Second, the supply of political resources (positions) available to distribute in exchange for support is inherently limited. Thus, there are inevitable losers in any competition for positions among clients lower in the elite hierarchy (Gould, 1996); this can undermine incentives to cooperate. Such contestation undermines elite morale and cooperation, and in the extreme may result in defections or factionalism. Third, deviations from pure hierarchy in patronage pyramids (such as the absence of a single apex or clients loyal to multiple patrons) undermine top-down authority, the main strength of patronage systems, creating further potential for conflict.

Despite these problems, patronage systems are empirically common. One possibility is that purely hierarchical patronage systems are unstable in competitive elites, and that regimes either tend to close down elite competition, tending towards (neo-) patrimonialism, ${ }^{4}$ or transition towards more inclusive patterns of elite coalition formation. Patronage systems are likely to emerge in postconflict settings as political leaders forged in the heat of armed conflict attempt to reproduce military hierarchies when assembling elite coalitions. In the shifting political arena of a regime in the process of formation, direct loyalty may in effect be the only game in town. In some cases, these leaders succeed in imposing top-down hierarchies, suppressing elite competition and building neo-patrimonial regimes (as in North Korea or Zimbabwe). When no leader is able to monopolize political control, elite competition motivates leaders to seek more inclusive strategies of elite coalition formation. If this expectation is correct, patronage will dominate coalition formation strategies in the early stages of regime formation and assume more mixed and attenuated forms as regimes consolidate. This does not imply that patronage disappears, but rather that it takes on less strictly hierarchical forms or blends with other strategies.

\footnotetext{
${ }^{4}$ Patrimonial regimes often involve patronage, but not all patronage systems are patrimonial. In keeping with the classic definition, patrimonialism refers to the equation of the state with the ruler's personal property, not to elite structure or the logic of exchanges.
} 


\subsection{Sponsorship systems and network extension}

A second problem with the pyramidal patron-client model is that the assumption of strict hierarchy may be too demanding for competitive elites. The pure patron-client model is a formalization of feudal social relations (Martin, 2009; Montgomery, 2007), and the image of rigorous pyramidal hierarchies is more likely metaphor than a literal description contemporary elite networks (c.f. Grindle, 2012: 20). Relaxation of the assumption of strict hierarchy gives way to a "sponsorship" model in which competing "big men" mobilize their armies of clients (Martin, 2009). This model is a variant of the patronage system which involves exchanges of positions for loyalty, but allows for multiple patrons, the absence of a single apex, and horizontal ties which offset strict hierarchies. At a structural level the model implies a diffuse, web-like structure rather than a strict pyramidal hierarchy.

The sponsorship model suggests that in the context of stratified organizational hierarchies, clients may seek multiple patrons in order to seek career opportunities (Martin, 2009). This implies that rather than — or in addition to - connections to senior leaders, the size or extent of elites' social networks is a valuable resource. This hypothesis is consistent with a long line of research on social capital showing that network extension impacts career outcomes (Lin, 2002). To the extent that elite coalition formation resembles a political labor market, larger elite networks are a valuable resource. This generalized sponsorship-as-social capital model is consistent with the hypotheses stated above: direct (and possibly indirect) ties to a senior leader confers a promotion advantage. However, the sponsorship model also makes three additional predictions which are inconsistent with the pyramidal patronage model. First, if acquiring ties to more patrons is an advantageous career strategy, then elites with more patrons may be more likely to achieve promotion. Second, if "clients" who are themselves "patrons" with their own extensive networks are seen as valuable allies (possibly because they deliver larger networks of loyal followers), then they are also more likely to be promoted into elite coalitions. Third, in the context of the present study, I allow for the possibility that horizontal (patron-to-patron or client-to-client) ties may reflect a kind of "quasi-patronage."

Relative to strictly hierarchical patronage systems in which only elites directly or indirectly 
subordinate to the senior leader are considered loyalists, the sponsorship model represents a more deferential strategy of elite coalition formation. For example, by choosing elites with access to more patrons, leaders may seek to placate competitors by rewarding their subordinates. If (as suggested above) elites tend to adopt more inclusive strategies of elite coalition formation as regimes consolidate, we should expect a shift towards patterns consistent with the sponsorship model over time. Conversely, in a regime formation context in which personal loyalty remains the currency of elite politics, ties to multiple patrons may actually be a disadvantage. Elites who serve more than one patron appear to have "divided loyalties" and therefore seen as untrustworthy. This suggests that in some contexts, elites with broader networks may actually be less desirable coalition partners.

However, while the sponsorship model may be a more realistic model of elite network structure than pure patronage in this context, it is not clear that this "extended patronage" strategy is a durable approach to elite coalition formation. Competition between patrons can lead to factional divisions, resulting in elite conflict (Martin, 2009). Moreover, when clients serve more than one patron, they face normative dilemmas over who to follow if these superiors conflict (Montgomery, 2007). Thus, while the sponsorship model implies a more deferential strategy of elite coalition formation than strictly hierarchical patronage, it is unlikely to provide a durable basis for elite coalition formation.

\subsection{Brokerage}

At a structural level, the web-like sponsorship model implies that there are numerous structural holes in elite networks. A long research tradition argues that brokers who span these gaps perform better, are more influential, or have more power than those far from structural holes (Burt, 1992; Fernandez and Gould, 1994; Gould, 1989; Granovetter, 1973; Simmel, 1950; Stovel and Shaw, 2012). This "horizontal" brokerage is more general than the "vertical" brokerage exercised by intermediaries in patronage relationships. ${ }^{5}$ Elites occupying brokerage positions have access to multiple channels for information and communication (Burt, 1992) and exercise control over exchanges they

\footnotetext{
${ }^{5}$ Specifially, vertical brokerage is a subtype of the "gatekeeper" role identified by Fernandez and Gould (1994), in which a broker mediates in a hierarchical relationship across a status divide. For example, Kettering (1986) describes brokers in 17th centuring France as intermediaries between the royal court and the (lower status) provincial nobility. However, not all gatekeeper positions are equivalent to vertical brokerage.
} 
intermediate (Marsden, 1982; Stovel and Shaw, 2012). More generally, brokers help to "establish the situation in which exchanges or settlement of disputes can take place" (Gould, 1989: 535). From this standpoint, brokers are middlemen who "[bring] persons with divergent interests together and [show] them how, in some setting or context, their interests coincide" (Stovel and Shaw, 2012: 149).

While these theories overlap with the robust action approach of Padgett and Ansell (1993), the latter centers on the unique central positions of dominant political players, such as Cosimo de Medici or Deng Xiaoping (Padgett and Powell, 2012). This theoretical framework is based on the brokerage performed by coalition builders, rather than the benefits that other brokers provide as allies. However, including brokers in elite coalitions may solve some problems that plague patronage strategies. In a competitive and heterogeneous elite, bridging gaps between clusters or groups provide two distinct benefits to senior leaders. First, brokers deliver mediation capacity: the ability to resolve intra-elite disputes, negotiate exchanges, and spread information through informal channels. These capacities can be useful in building and sustaining support for policy agendas advanced by those at the top. Second, including brokers in elite coalitions has a potential symbolic value. Network ties are not only conduits for information and exchanges, but also visible signs of alliance and affinity (Podolny and Baron, 1997). In closed political elites, competitors' network positions are valuable political information. Elites know who their competitors' allies are; social ties provide information about alliance, affiliation, and likely behavior. Brokers' split affiliations provide motivation to cooperate with otherwise disconnected or loosely connected groups. Such ambiguous political affinities and identities enable brokers to project impartiality with respect to competitors (Fernandez and Gould, 1994; Padgett and Ansell, 1993; Stovel and Shaw, 2012), making brokers valuable allies in elite coalitions. By including brokers in their coalitions, senior leaders signal inclusiveness and deference to other members of the elite.

However, theorists have also argued that the salience of brokerage varies across contexts. As noted above, Gould (1989) argued that brokerage matters most in "factionalized" or "polarized" elites and less so when consensus increases. This argument rests on the idea that stable cleavages create "'synapses' which make brokerage not only possible but necessary for the resolution of 
conflict" (Gould, 1989: 536). At the same time, Gould and others (Stovel and Shaw, 2012) also argue that ambiguous loyalties can be a liability as well as a resource. While Gould argued that this tension requires that brokers limit open pursuit of their own goals, others develop this line of thinking further, arguing that this "dark side" of brokerage may actually be a disadvantage in some contexts (Stovel and Shaw, 2012; Barnes et al., 2016; Krackhardt, 1999). For example, Barnes et al. (2016) argue that occupancy of brokerage positions may have negative consequences in "fragmented" and "competitive" contexts.

These arguments rest on the assumption that coalitions are fixed and exogenous. ${ }^{6}$ However, this assumption conflicts with literature stressing the role of brokerage in constructing coalitions (McAdam et al., 2001; Hillmann, 2008b). To the extent that brokers perform the mediation and signaling roles just discussed, the presence of brokers in elite coalitions should be expected to reduce factionalism. More precisely, avoiding factionalism and conflict may be a strategic goal of including brokers in an elite coalition. Thus, from the perspective of coalition formation, brokers are likely to be politically salient absent factionalism or polarization to the extent that including brokers in a coalition is a strategy to close gaps, prevent internal conflicts, and enhance elite cooperation.

In this paper, I gain empirical leverage over these questions by exploiting data that encompass both the formation and subsequent consolidated rule of a closed political elite. Although the contrast between regime formation and consolidation is not the same as the distinction between factionalism and consensus, these concepts are empirically correlated. Elite factionalization and fragmentation generally decline with regime consolidation (c.f. Burton and Higley, 1987). Conversely, elite consensus (in the minimalist sense of behavioral conformity with the rules of the political game) is greater by definition in consolidated regimes. While there may be cases in which regime consolidation results in the emergence of a polarized factional structure, this was not the case in Mexico. In particular, there is no evidence that factionalism increased in the Mexican political elite as the regime consolidated. Given this, the claim that brokerage is most salient in factionalized contexts implies that any association between brokerage positions and cabinet ap-

\footnotetext{
${ }^{6}$ Although Gould (1989) did not use the term "coalition" in this context, the contrast he drew between "factionalized" and "consensual" elites was based on previous work describing elite coalition structures (Laumann and Pappi, 1973; Laumann et al., 1977).
} 
pointments should be greater during the period of regime formation rather than following regime consolidation. On the other hand, if including brokers in elite coalitions is an effective strategy for fostering cooperation and limiting elite conflict, brokers will be most likely to be included in elite coalitions in consolidated regimes. Finally, if the tensions inherent in brokerage are so great as to lead to a penalty for ambiguous alliances, I expect this negative effect to hold in periods of regime formation.

To summarize, patronage (in both its classical pyramidal formulation and the sponsorship variant) and brokerage models each imply testable hypotheses regarding strategies of elite coalition formation. These hypotheses sit at the juncture of structure and agency: they imply that elites' positions in a relational structure inform the strategic political action of a political leader forming a coalition. If the arguments presented above are correct, we should see broad shift away from top-down strategies of centralization (such as hierarchical patronage) and towards more inclusive mixed strategies incorporating sponsorship and brokerage as regimes consolidate. This hypothesis is not a deterministic claim about a causal linkage between consolidation and coalition formation strategies, but rather a historical generalization about emergent patterns of elite political action. This paper analytically isolates coalition formation from the complexity of elite behavior in order to gain empirical traction on this intersection of elite networks and political action.

\subsection{Between patronage and meritocracy}

Many scholars contrast patronage structures and informal networks with bureaucratic rationalization (e.g. Grindle, 2012: 21). Weberian bureaucratic structures are characterized by meritocratic recruitment and career predictability, thought to contribute to formation of effective, high-capacity states (Evans, 1995; Evans and Rauch, 1999). In the 20th century the Mexican state developed a moderate level of state capacity with some pockets of efficiency, though also persistent corruption (Evans and Rauch, 1999; Portes and Smith, 2012). Particularly in its later years, technocrats dominated the regime (Centeno, 1997; Babb, 2001); for example, the last several PRI presidents were career Treasury officials with advanced degrees in economics or public administration. These considerations raise the question of the extent to which bureaucratic rationalization, rather than 
network structures and processes, account for elite coalition formation. However, there are two theoretical reasons to question a simple opposition between networks and bureaucracy. First, theories of Weberian state structures refer to the middle ranges of the administrative hierarchy (Carpenter, 2001); even in the most rationalized of states, members of the cabinet or other senior leadership bodies are inherently "political appointees." Second, networks and meritocracy are not mutually exclusive; for example, Evans (1995: 49) argues that even in a robust bureaucratic state such as Japan, "informal networks give the bureaucracy an internal coherence and corporate identity that meritocracy alone could not provide." To the extent that network position influences performance (Burt, 2004), there is no reason to see networks and meritocracy as opposed.

Nevertheless, from a methodological standpoint endowments of merit — political or administrative skill, experience and performance - are a potential source of omitted variable bias. To the extent that network position is correlated with (but not itself the cause of) these endowments, any correlation between networks and appointment to an elite coalition may be spurious. This is a particular concern insofar as informal networks and career experience are inter-related. For example, elites with more varied career experience are likely to be more knowledgeable and better able to coordinate with different areas of the government, a relevant political skill. This varied career experience may be reflected in elite networks as officials accumulate more or more diverse ties. For this reason, I introduce below several control variables that capture elements of political experience and knowledge most likely to be correlated with network position. It is not possible, however, to fully control for all aspects of merit, not only because of the inherent difficulty of measuring political ability but because the relevant aspects of merit may be idiosyncratic. For example, some elites could be valued for technical economic expertise while others for their skill in political negotiation. Given that the goal of this paper is to test network theories of elite coalition formation, what is most important is to control for indicators of merit that may be correlated with network position, rather than fully account for all aspects of political skill. 


\section{Elite networks and coalition formation in Mexico}

From 1929 through 2000 the Institutional Revolutionary Party (PRI) dominated the Mexican political system, controlling the executive branch and nearly all other political institutions. Single-party dominance made the Mexican political elite closed but competitive: the PRI was nearly the only arena for political competition, but within organizational boundaries competition for power was fierce. Despite this competition, political sociologists and political scientists have long emphasized the highly centralized, hierarchical, and disciplined character of this regime (Centeno, 1997; Weldon, 1997; Smith, 1979). The regime's capacity for elite cooperation is manifest in its adept management of leadership turnover: presidential power exchanged hands in regular six-year cycles (sexenios); although elections were held, in practice the PRI invariably won (Magaloni, 2008; Greene, 2007). As a result, in practice each president chose his successor (the so-called tapado), a choice known as the "dedazo." This informal institution was the most visible manifestation of a set of informal "rules of the game" regulating elite competition (Centeno, 1997; Langston, 2006; Magaloni, 2008; Schlefer, 2008; Smith, 1979). These informal rules gave the president the right to unilaterally dictate his successor but limited the universe of eligible candidates, while also proscribing active mobilization in favor of preferred candidates. The rules also threatened political ostracism to elites who openly criticized the anointed heir, but held out the carrot of continued affiliation with the regime in exchange for support for the new president (Schlefer, 2008).

Some historians challenge this monolithic, top-down model (e.g. Joseph and Nugent, 1994; Rubin, 1997); as one historian puts it, the regime "was never as powerful, coherent, and extensive as many students of modern Mexico have supposed; even in its heyday, it was, like Emmental, full of holes" (Knight, 2014: 66). However, this literature focuses on regional politics, labor conflict, social movements and popular culture, rather than elite politics in the central government. Nevertheless, the argument that the regime's capacity for top-down control was more limited than often assumed calls for a closer examination of centralizing political strategies, such as patronage appointments.

Broadly speaking, one implication of the porous character of the PRI regime is that bridging internal divisions was likely an important goal of coalition formation. Several distinct fault lines existed within the party. The PRI internalized both "left" and "right" wings: President Lázaro Cár- 
denas (1934-1940) adopted "revolutionary" policies of land redistribution and nationalization, but subsequent presidents slowed redistribution and implemented more pro-business economic policies (Hamilton, 1982; Middlebrook, 1995). Similarly, the 1970s saw a shift towards "populist" economic policies, culminating in the divisive nationalization of the banking system in 1982, followed by a rapid lurch towards privatization and free trade in the 1980s (Babb, 2001; Centeno, 1997). Overlaying this left/right division were tensions between party-minded "politicos" and policy-oriented "tecnicos" (Centeno, 1997). There were also generational divisions, such as tensions between revolutionary generals and civilian elites in the early years and between so-called "dinosaurs" and modernizing technocrats in later decades. This heterogeneity took the form of complex, crosscutting cleavages rather than polarization between competing factions. The term "faction" itself is rare in scholarship on the Mexican political system, and primarily used to refer to the regime's early years. ${ }^{7}$

The relative absence of leadership conflict and explicit factionalism in the consolidated Mexican political system is clearest when compared historically to the early period of regime formation, characterized by conflictive patterns of elite competition that emerged following the revolution. In the post-revolutionary period, elites attempted to monopolize power by circumventing the constitution prohibition of re-election (accomplished by President Álvaro Obregón in 1928 prior to his assassination) or exercising de facto control (as achieved by President Plutarco Elias Calles during the so-called maximato of 1928-1934). Calles established the National Revolutionary Party — antecedent to the PRI — in 1929 in order to contain these elite struggles (under his own dominance); however, leadership conflict continued within the framework of the party. President Lázaro Cárdenas (1934-1940), though initially backed by Calles, wrested control of the party organization and sent Calles into exile. In the 1940, 1946 and 1952 electoral cycles, elites contested the presidential dedazo by forming opposition party vehicles to promote their own ambitions: behavioral conformity with the rules of the game could not yet be taken for granted. In 1940 and 1952, the specter of a return to violent struggle (including some minor skirmishes) accompanied these defections.

\footnotetext{
${ }^{7}$ In several major works on the Mexican political elite (Camp 2002, Centeno 1997, Schlefer 2008, Babb 2001, Magaloni 2008) I find few uses of the term "faction." Most references to factions refer to the period before the 1950s or the leadership conflict of 1988 , discussed below.
} 
Moreover, in the 1952 electoral cycle, President Áleman openly flirted with extending his power through reelection or by appointing a puppet, raising again the specter of the monopolization of power (Schlefer, 2008). This elite conflict partly reflected the competition between revolutionary (or populist) Cárdenistas and the more conservative elites dominant after 1940.

As defined above, regime consolidation refers to behavioral conformity with formal or informal rules of elite competition, particularly insofar as elites develop stable expectations about competitive behavior. In a basic sense, consolidation generally increases with time the longer that violations of this behavioral conformity remain rare. However, there may also be discontinuities or turning points (Abbott, 2001: ch. 8) in regime consolidation. From a historical vantage point, the mid1950s appears to be such a turning point: the 1952 electoral cycle was the last major intra-elite conflict over the presidential succession (at least until 1988, a point I return to momentarily). A large body of work on the Mexican political system supports the contention that significant leadership conflict ended in the 1950s (Reyna, 1985; Schlefer, 2008; Centeno, 1997; Cosío Villegas, 1975; Magaloni, 2008). The 1952 electoral cycle has been called "the last open struggle" between "factions" of the "Revolutionary family" (Reyna, 1985: 105) and "the last serious opposition campaign before the political system was fully consolidated" (Schlefer, 2008: 86). According to Centeno (1997: 55), "the defeat of the dissident movement... in the election of 1952 marked the final victory of the right wing of the political elite over the 'Cardenistas' as well as the consolidation of political control by the central apparatus of the party." Similarly, a leading Mexican historian argued that "the true period of the Tapado" (that is, the informal institution of presidential succession by dedazo) began with the succession of 1958 - the following electoral cycle (Cosío Villegas, 1975: 139).

This historical discontinuity is a relative (rather than absolute) indicator of regime consolidation. Nevertheless, it is clear that conformity with the rules of the political game was greater after the mid-1950s than before. If the PRI regime can plausibly be described, in Gould's terms, as "polarized" or "factionalized," it is between Cardenas' break with Calles through the early 1950s. Whether or not one defines Cárdenismo and the right as polarized "factions" (Reyna, 1985: 105), it is clear that divisions in the elite were greater before 1952 than after. Thus, based on the end 
of contested leadership cycles in 1952, I define the period prior to the mid-1950s as one of regime formation and the subsequent period as one of consolidated rule. As just noted, this periodization has substantial support in the literature on the Mexican political system.

What is more controversial is whether there were significant variations in behavioral conformity with the rules of the game in later periods. As noted, the major exception to the otherwise smooth post-1950s transfer of presidential power was the 1988 challenge to the presidential dedazo by Cuauhtémoc Cárdenas (the son of former president Lázaro Cárdenas), "the most serious division in the Mexican political elite since the 1950s" (Middlebrook, 1988: 129). Responding to the marginalization of the party's "left" wing, Cárdenas formed a movement within the PRI in an attempt to to democratize the leadership selection process. When this failed, he ran for president as the candidate of an ad hoc coalition and then created the opposition Party of the Democratic Revolution (Bruhn, 1997). Cardenas' attempt to influence the presidential succession and subsequent defection was a clear departure the "rules of the game." On the other hand, it is not clear that this episode can be considered a reversal in regime consolidation. Despite the importance of Cárdenas' defection to the development of an opposition party, the impact on the PRI elite was relatively contained. Only Cárdenas himself and a small group of supporters actually left the party ${ }^{8}$ suggesting that Cárdenas' defection was relatively sui generis. ${ }^{9}$

For these reasons, in the empirical analysis reported below I take the first sexenio not marked by an internal conflict over the presidential succession - that is, 1958 - as the beginning of the period of the regime's consolidated rule. The goal of the analysis is to discern broad emergent patterns in elite political behavior, rather than investigate the particular political dynamics of shorter periods, which is difficult given the data available and modeling challenges. For similar reasons, the analysis does not address the end of the PRI regime, leaving such changes for future work. ${ }^{10}$

\footnotetext{
${ }^{8}$ Although some accounts have emphasized the centrality of PRI defectors to the formation of the PRD, Greene (2007: 154) finds that only a small number of early PRD members were former PRI members. Similarly, in the dataset described below, I find only 7 defectors from the PRI before 1994 among hundreds of elites.

${ }^{9}$ Moreover, consolidation is an asymmetric process: deviations from the rules of the game do not have the same impact after several decades of behavioral consistency that they do when the rules are still in the process of formation.

${ }^{10} \mathrm{It}$ is worth underscoring that the fall of the PRI in 2000 was not primarily the result of a breakdown inh the "rules of the game" that governed competition among party elites, but the ability of an alternative party elite to achieve electoral success. Indeed, the PRI remains a relevant political organization and recaptured the presidency in 2012 .
} 


\subsection{Elite networks in the regime}

Analysts of the Mexican political system have long recognized the importance of elite networks, particularly patron-client relations, to coalition formation. Descriptions of informal elite structures known as camarillas, political groups (grupos), or teams (equipos) closely echo the patron-client model introduced above. For example, Centeno (1997: 147) describes camarillas as "a series of vertically and horizontally interlocking, roughly pyramidal, groups. Prospective politicians and bureaucrats attach themselves to a patron or 'godfather' who will provide either a position or an introduction... The patron offers a job or increased influence, the client offers loyalty and trust" (c.f. Camp, 1990; Grindle, 1977). On this view, camarillas determine "who rises to the top of the political system, the path taken by successful politicians, and the designation of individuals to specific political posts" (Camp, 1990: 85). At the top of the political hierarchy, the cabinet is often interpreted as the President's personal camarilla (Camp, 1990; Hernández Rodríguez, 1987). Some descriptions suggest that the President is "at the very apex of a pyramidal network" (Centeno, 1997: 148), implying a strict hierarchy with a sweeping capacity for top-down control.

Other descriptions of the structure of the Mexican elite imply a partial, web-like hierarchy consistent with the sponsorship model. For example, Schlefer (2008: 46) argues that "Mexican grupos were fluid, defined by degrees of friendship, trust and mutual benefit, not a binary mathematical function. The leader had his equipo - his team of immediate subordinates — but over time he placed equipo members in other areas of the administration, creating a broader and somewhat less tight-knit grupo." Similarly, Centeno also notes that an upwardly mobile politician "acquire[s] more patrons whose networks she serves to connect... The higher in the hierarchy the camarilla, the more interconnected it becomes" (Centeno, 1997: 147). This implies that patron-client relationships were not exclusive; rather, establishing connections to multiple patrons was part of a successful career. From the theoretical perspective introduced above, these descriptions are more consistent with the sponsorship model than strict pyramidal hierarchy.

The observation that local political groups interconnect and overlap implies that there are substantial brokerage opportunities available in the Mexican elite network. Yet despite substantial attention to vertical brokerage between party elites and mass organizations (Grindle, 1977; Carlos 
and Anderson, 1981), there is little research on intra-elite, horizontal brokerage. However, native accounts of political actors suggest that avoiding conflict and fostering cooperation was a motivating force in cabinet appointments. For example, President Carlos Salinas de Gortari (1988-1994) remarked that a key objective in selecting cabinet members was achieving "cohesion among the different currents that... existed within the PRI, and that's why it was a cabinet that covered a wide spectrum" (Castañeda, 1999: 276). Similarly, President Miguel de la Madrid emphasized the importance of "communication and collaboration" within the cabinet in order to to avoid "internal struggles" (Hurtado, 2013: 58). One role for brokers was mediating exchanges of information in a context in which political communication was inherently risky. For example, de la Madrid observed that "people do not want to express themselves freely in front of the President, because they fear making a mistake" (Hurtado, 2013: 716). Less intuitively, presidents themselves face difficulties in sending politically charged messages, because executive pronouncements tended to be "understood as decisive" and invested with often unintended meanings (ibid.). For these reasons, de la Madrid noted that a "system of messages" passed through political "intermediaries" allowed him to "receive the information I desired" (ibid). While these statements provide hints of the strategic considerations involved in cabinet appointments, the Mexican political elite (like many elites) is highly opaque; politicians typically do not divulge their political strategies. For this reason, a quantitative approach that infers the logic of elite coalition formation from appointment patterns is an important addition to research relying on qualitative sources.

\section{Data and methods}

A uniquely rich source of career history data is available for the Mexican political elite (Camp, 2011). ${ }^{11}$ In addition to presidents, governors, and members of congress, the data source includes the population of cabinet secretaries and assistant secretaries (as well as additional positions discussed below) over a period of more than seventy years (1935-2009). I extracted and coded the full educational and career histories of individual elites from the source, including records of roughly 9900 appointed positions in federal and state governments, 5800 records of higher education experience,

\footnotetext{
${ }^{11}$ I thank Roderic Camp for generously making the source available in electronic format.
} 
3300 party appointments, and 300 governorships and presidencies.

\subsection{Defining candidates for cabinet appointment}

As noted above, this paper focuses on a crucial moment of elite coalition formation: the appointment of cabinet secretaries (henceforth "secretaries" or "cabinet members"). The Mexican cabinet is the highest body in the executive branch following the president. During the period of one-party dominance, the cabinet was the key locus of policy-making: power was concentrated in the federal bureaucracy, rather than the congress or regional governments. The PRI regime was "a government of functionaries" in which the bureaucratic apparatus of the state controlled the party, rather than the other way around (Centeno, 1997: 51). Although executive powers had some formal limits, the President could submit laws to congress, which rarely if ever opposed the executive, and the judiciary was docile (Weldon, 1997). The cabinet was also the critical stepping-stone to the presidency: between 1940 and 2000, all presidents held a cabinet position in the administration preceding their own. Thus, cabinet appointments are a key aspect of elite coalition formation in Mexico.

Analytically, assessing the determinants of cabinet appointment requires identifying a pool of eligible "candidates," some of whom achieved promotion while others did not. This comparison is made possible by the fact that during the period of PRI dominance, most civilian cabinet members were primarily career bureaucrats selected from the ranks of second-tier administrative officials (rather state governors or members of congress, for example). ${ }^{12}$ This is shown in table 1 , which summarizes pathways to the cabinet among observed secretaries from 1940 to 2000. The most common gateway to the cabinet - the highest appointed position held prior to cabinet appointment - is the position of assistant secretary, the second-highest position in the executive branch $(37 \%$ of secretaries). An additional $19 \%$ of secretaries reached the cabinet after holding the positions of oficial mayor (a senior administrative official), director general of major autonomous state organizations (for example, the state-owned oil company PEMEX), or federal attorney general. ${ }^{13}$

\footnotetext{
${ }^{12}$ Because occupants of the two military cabinet secretariats followed different career paths; this paper focuses on civilian cabinet members.

${ }^{13}$ Although the attorney geneal is also a cabinet member, as with military secretariats these officials followed more specialized career paths. I exclude them because of the lack of an adequate comparison group of candidates.
} 
Together, $56 \%$ of secretaries took this modal career path to the cabinet. Crucially, the data source includes the near-complete population of occupants these second-tier positions during the 19352000 period. This enables comparison of observed secretaries with a set of eligible candidates who did not achieve appointment.

[Table 1 about here.]

However, the remaining $44 \%$ of secretaries followed more idiosyncratic career paths. $17 \%$ of cabinet members had only reached the position of secretariat director general (the third level of the administrative hierarchy) and an additional $7 \%$ only the position of director (fourth level). These secretaries "jumped the queue," achieving appointment to the cabinet without passing through intervening levels of the administrative hierarchy. Such leap-frogging might be evidence of a qualitatively different career path; for example, experience as a state governor or member of congress may have been the stepping stone to the cabinet in these cases. As table 1 also reports, electoral experience was moderately common, though not the norm, among cabinet members. However, electoral experience was not substantially more common among secretaries who "jumped the queue" from the third and fourth tier than among those that followed the modal career path. ${ }^{14}$ Thus, electoral experience does not appear to explain these leap-frogging appointments. However, electoral experience is indeed over-represented among secretaries whose career paths are classified as "other." The analysis reported here excludes this remaining $20 \%$ of secretaries, an idiosyncratic and heterogeneous set for which no clear comparison group is available in the data.

The composition of cabinet members' career paths is an analytical challenge. Although the comparison of appointment from the "second tier" is straightforward, analysis of the "queue jumpers" must address possible selection bias. While the data source includes the universe of elites who reached second-tier positions, it does not include the population (or a random sample) of those elites whose highest position was in tiers three and four. This problem is endemic to studies of political elites: nearly any feasible data collection process selects those who "reached the top;"

However, because several attorneys general were later appointed to other cabinet positions, I include attorneys general as candidates.

${ }^{14}$ There is no identifiable statistical difference in pairwise comparisons between the pooled positions on the modal career path and the "queue jumpers" groups. However, the difference between the "other" group and the modal group is statistically significant. 
collection of systematic data on those who failed is difficult, costly and, in historical contexts such as this one, often impossible.

I address this selection issue by analyzing three nested subsets of the data. The first subset is restricted to candidates on the modal career path - those who reached the second tier of the administrative hierarchy in the twelve years prior to the appointment period. ${ }^{15}$ The second adds to the previous subset all officials in the dataset who have reached the third level or higher (secretariat director general) prior to the beginning of the appointment period. Similarly, the third subset adds officials who had reached the level of director or higher.

Methodologically, subset one provides the strictest control and encompasses more than half of observed secretaries; I therefore give prominence to this subset and use subsets two and three to confirm the analysis using the broadest possible proportion of the observed cabinet. Two points deserve emphasis here. First, analysis of subsets two and three assumes that elites who eventually reached the second tier are representative of the pool of competitors for cabinet positions. While it is difficult to verify this assumption, given the absence of data on the omitted officials, it is highly plausible. Secretaries who "jumped the queue" are anomalous not only in a statistical sense, but also in the substantive sense that they skipped over the explicit ranking of state positions. Thus, assistant secretaries (and elites known to progress to the cabinet or assistant secretary level) represent the plausible pool of competitors. Second, any bias in subsets two and three is likely to be conservative with regard to brokerage. I test whether brokers are more likely to be appointed to the cabinet; however, a broker may have to "wait his turn" until he reaches the second tier of the elite; only in relatively exceptional cases are elites able to "jump the queue." Thus, a broker at tier three who is promoted once reaching tier two will tend to bias estimates of the difference between successful and unsuccessful candidates downward. Results for subsets two and three are more tentative than for subset one because of these assumptions, but this strategy permits a more complete analysis by including a higher proportion of all secretaries.

\footnotetext{
${ }^{15}$ I use the 12-year cutoff because most secretaries (89\%) on the modal career path that achieved promotion did so within two sexenios. I include the 11 secretaries who took more than 12 years between reaching tier 2 and the cabinet in subset in order to maximize the information about secretaries; omitting them does not alter the results.
} 


\section{$3.2 \quad$ Inferring elite networks}

Drawing on longstanding observations among scholars of the Mexican political elite, I infer six types of network ties (summarized in table 2) from the career and educational histories of elite officials. These ties are indicators of underlying relationships of acquaintance, familiarity and trust. Ties do not necessarily connote friendship; rather, I assume only that shared experiences increase elites' capacity for communication, exchange and cooperation. Career histories permit inferences about vertical patron-client ties in two ways. First, senior officials - such as cabinet members and state governors - recruit trusted allies as their subordinates (e.g. Grindle, 1977: 38). Drawing on this insight, I define a recruitment tie as present between elites $i$ and $j$ at time $t$ if $i$ is a secretary or governor and $j$ begins a new position $p_{j t}$ under $i$ 's tenure (that is, $p_{j t} \neq p_{j t-1}$ ). Recruitment ties are also present between advisers and personal assistants and the officials they serve. ${ }^{16}$ Recruitment ties are directed, with the direction pointing from the senior official to the subordinate. A second source of vertical ties are relationships between professors and students. A somewhat surprising feature of the Mexican political system is the ubiquity of these relations in political recruitment; many political figures were "taxi professors" who shuttled back and forth between government offices and the classroom (Babb, 2001: 34-36). For example, one former Treasury secretary listed five out of his six most influential professors as public figures, including another cabinet member who had initially recruited him (Camp, 1976). Similarly, President Miguel de la Madrid was a student of his predecessor, José López Portillo, who also appointed his former student to a cabinet position. Based on these examples, I code a mentorship tie as present between $i$ and $j$ when $i$ is a professor and $j$ a student of the same subject, in the same university, in the same year.

[Table 2 about here.]

Other information available in the career histories allows inferences about horizontal relationships between peers, without necessarily revealing implicit asymmetries. First, joint work experience establishes ties of acquaintance and familiarity that become a resource when elites later re-encounter one another. For example, President de la Madrid (1982-1988) knew many of his cab-

\footnotetext{
${ }^{16}$ For example, an official holding the position "adviser to the assistant secretary of planning" has a tie to the assistant secretary of planning.
} 
inet appointees from his own long career in the federal bureaucracy; he had worked alongside his Treasury secretary in two different state organizations (Hernández Rodríguez, 1987). To capture this, I code experience ties as present between actor $i$ and $j$ in organization $o$ at time $t$ if $i$ and $j$ previously worked together in a different organization $\left(o_{t} \neq o_{t-1}, o_{t} \neq o_{t-2}\right.$, etc.). In other words, elites acquire an experience tie the second time they work together. Party ties present between pairs of elites who held positions in either national or state party organizations and campaigns are a variant of experience ties. Second, relations between students last into subsequent political experience; for example, President Miguel Áleman recruited many of his former law school classmates into government service (Camp, 1976). Thus, co-education ties exist between elites $i$ and $j$ if they studied the same subject in the same university in the same year. Finally, a similar observation applies to professors; networks formed in the law and economics departments of major public and private universities later moved into state positions (Babb, 2001). Collegial ties are present in a dyad if the actors both taught the same subject in the same university in the same year.

[Table 3 about here.]

Although vertical ties based on recruitment and mentorship contain information about asymmetric relationships, lending themselves to a patronage interpretation, horizontal ties based on experience, co-education and other sources do not necessarily convey this information. Nevertheless, when (for example) the President appoints a former classmate (i.e. a horizontal tie) to the cabinet, previous scholarship has often interpreted this as an exchange of position for loyalty. This suggests that horizontal ties may reflect "quasi-patronage" relations that are imperfectly represented in the data. While there are limits the inferences that can be drawn from career history data, it is important to include all the available information about elite ties. Thus, in order to calculate brokerage measures as discussed below, I aggregate all of the network information into a single binary, directed network that treats a tie as present if any of the six ties is present (if both vertical and horizontal ties are present, the relationship is treated as symmetric). ${ }^{17}$ This aggregation reflects the empirical distribution of ties, summarized in table 3, which reports levels

\footnotetext{
${ }^{17}$ Aggregating ties in this way discards potential information about tie strength derived from the duration or multivocality of relationships. In the present paper, I prefer not to make this additional, potentially debatable, assumption.
} 
of density, connectivity and the proportion of isolates for each tie type and the combined aggregate. Recruitment, mentorship and co-education ties account for most of the density in the aggregate network, while career experience, party and collegial ties make a smaller contribution. The aggregate network achieves a high level of connectivity; in all periods, networks consist of a single main component with few outliers. Because this highly connected network emerges only after ties are aggregated, and because both education and career ties are indicators of similar underlying relationships of acquaintance and trust, I use this aggregate to measure network size and brokerage positions in the main specification. I disaggregate vertical and horizontal ties in measures of patronage and network extent analyzed in supplementary models as explained below.

\subsection{Network measures}

In order to measure the network positions of candidates for appointment to the cabinet, I first add to each subset the president, outgoing president and any politically active former presidents, as well as incumbent cabinet secretaries. Inclusion of these senior political figures is crucial to the measurement of network location, since position depends on relations with incumbent elites. Network measures are calculated based on this expanded subset, but presidents and outgoing secretaries are excluded from the appointment analysis. ${ }^{18}$ Measures of network position are calculated based on networks observed in the final year of the administration preceding the appointment period.

In order to test the effect of presidential patronage on cabinet appointments, I measure the shortest path (geodesic) between candidates for appointment and the president. As just noted, only vertical recruitment and mentorship ties are consistent with a strict interpretation of patronage; however, horizontal relationships may reflect a form of "quasi-patronage" that is imperfectly reflected in the data source. For this reason, I disaggregate vertical and horizontal paths. I enter both vertical and horizontal ties in models as dummy variables; direct ties are captured by a variable which equals one a focal node's shortest path to the president has a length of one. A second dummy captures indirect (two-step) ties. Nodes tied to the president by paths of three or more

\footnotetext{
${ }^{18}$ I focus solely on the first appointment to the cabinet; re-appointments occur but are relatively rare and substantively distinct, making a systematic analysis difficult.
} 
ties, or isolated entirely, are the comparison group. ${ }^{19}$

I measure network extent reflecting additional patronage ties or other social capital using network degree, or the count of a focal node's ties. As noted, the main specification employs total degree, but supplementary models disaggregate degree effects for vertical and horizontal ties. Vertical in-degree, or the count of recruitment and mentorship networks in which a node is a subordinate, captures the number of patrons to which an elite responds. Conversely, the number of clients responsive to an elite is measured by out-degree in these vertical networks. Finally, degree in horizontal networks reflects the count of a node's peers in symmetric or "quasi-patronage" relationships.

Complex network indicators such as the brokerage measures introduced below are generally correlated with degree (Fernandez and Gould, 1994) because individuals must have substantial networks in order to occupy brokerage positions. Therefore, I carefully model the baseline effect of network degree in order to avoid confounding brokerage and network size. Because the degree distribution is skewed (as is often the case in network datasets) and network ties have diminishing returns, I transform raw degree scores by the log of $1+$ degree. Further, preliminary analysis showed that degree effects are best captured by an orthogonal polynomial specification (see discussion below). I also center all degree variables on their means to mitigate collinearity concerns.

There is a lively discussion of competing brokerage measures in the social networks literature (Freeman, 1978; Fernandez and Gould, 1994; Burt, 2010; Bruggeman, 2013). Varying measures reflect diverse data sources and theoretical motivations, but similar underlying intuitions. No indicator is perfect; therefore, in the interests of robustness I compute multiple brokerage measures. First, betweenness (Freeman, 1978) is a classic indicator of network centrality which measures the extent to which flows between alters depend on the mediation of a focal node. ${ }^{20}$ Betweenness is sometimes interpreted as a measure of "power" (Krackhardt, 1990; Faris and Felmlee, 2011), for

\footnotetext{
${ }^{19}$ Alternative specifications disaggregating elites tied to the president by longer paths and isolates yield similar results.

${ }^{20}$ Because the size of elite networks varies, I use size-normalized betweenness scores. In order to maximize the information contained in the data, I calculate betweenness based on shortest paths using directed ties, thus excluding relations (and chains of relations) from clients to patrons from the count of a focal nodes brokerage ties. In other words, if node $\mathrm{j}$ is a client of node $\mathrm{i}$ and $\mathrm{j}$ is also tied to $\mathrm{k}$, then $\mathrm{j}$ is not a broker between $\mathrm{i}$ and $\mathrm{k}$. The intuition underlying this choice is that clients have less ability to mediate relationships with their patrons than vice versa. This is a conservative approach to defining brokerage and is also consistent with the group-based method defined next. To reduce skewness, I transform this measure by the log of $1+$ betweenness in the regression models.
} 
reasons that derive from brokerage processes. Second, Fernandez and Gould (1994) proposed a modified version of betweenness that incorporates group memberships based on node attributes or inferred from the networks themselves (as in Gould, 1989). Because the elites examined here are all affiliated with the same political party, there is no single attribute variable on which to base group memberships; therefore, I infer groups from the network data themselves using the modularity approach (Newman and Girvan, 2004), as discussed below. I focus on the "inside" brokerage types Gould (1989: 100) (representative, gatekeeper and coordinator), because "outside" types are less informative, given the strategy used here to infer group memberships. ${ }^{21}$

\subsection{Meritocracy}

As noted above, the models control for endowments of political skill, experience and other aspects of merit that are potentially correlated with (but not explained by) network position. It is important to underscore that the definition of candidates for cabinet promotion introduced above holds experience substantially constant by conditioning inclusion in the analysis on reaching high levels in the administrative hierarchy. That is, only highly experienced elites are considered candidates for promotion, and reaching senior levels in the elite is likely to equalize many skill differentials. Beyond this, I control for remaining variation in skills by including covariates that are potentially correlated with network position. First, career diversity (measured as the number of substantive policy areas in which the elite has experience) captures possible contributions to endowments due to multifaceted career experience. Second, several studies have noted the rise of "technocrats" with advanced training, particularly in economics, as key players the regime (Babb, 2001; Centeno, 1997). I include an indicator for holding a graduate degree as a means of controlling for skills rooted in formal training. Third, for similar reasons, I also include a variable which measures the proportion of an elite's career spent in economic policy agencies. This measure accounts for the formation of valuable political skills acquired on the job in "technocratic" bodies — often considered to be the Mexican state's most efficient organizations. Fourth, a variable which measures the proportion of an elite's career spent in regional governments captures experience in managing state

\footnotetext{
${ }^{21}$ I use the standardized measures from the Fernandez and Gould method and transform this variable using a log-modulus transformation (results using an inverse hyperbolic sine transformation are extremely similar).
} 
and local affairs. Finally, although table 1 shows that there does not appear to be a distinctly electoral (as opposed to administrative) path to the cabinet, it remains possible that partisan and electoral experience "rounds out" administrative careers, making elites with these backgrounds more desirable allies. Thus, I include dummy variables coded one if the elite has ever held an elected or party leadership position.

In addition to these controls, for methodological reasons I include covariates which adjust for the varying stages of elite careers. In order to capture career aging, I control for years of experience at the beginning of the appointment period. In general, because the analysis includes only actors who are already close to the peak of their careers, this variable is expected to have a negative association with the likelihood of promotion, indicating that the likelihood of promotion to the cabinet declines as the potential candidates "age out" of candidacy. However, in the broader subsets which include elites who may or may not "jump the queue," I allow for a curvilinear association between experience and promotion probability, because the probability of appointment may rise as elites reach seniority and then fall as they "age out." In addition, subsets two and three include an additional control indicating whether an elite had reached the modal career gateway (in other words, whether the elite is part of subset 1).

\subsection{Model specification}

In order to distinguish between the early period of regime formation and subsequent consolidated rule of the PRI, I separate the data into the periods 1940-1958 and 1959-2000. This division of the data treats the $1952-58$ administration as the turning point in the process of consolidation. I include the 1952-58 sexenio in the regime formation period because all but two cabinet appointments during this administration occurred the first year of the administration — immediately after a contested leadership succession resulted in substantial leadership conflict. An alternative analytical approach is to pool the data and capture differences between periods by interacting the main effects of brokerage measures with period dummies. However, I prefer the split sample approach because it allows coefficients for control variables and degree effects to adjust to period-specific values (without introducing substantial multicollinearity by including multiple interaction effects 
with period dummies). The main substantive results concerning patron-client ties and brokerage positions are unchanged in a pooled model capturing period differences with interaction terms, reported in the appendix. Finally, as noted above some observers might interpret political events of the 1980 s as reflecting a reversal in regime consolidation. Although this interpretation is not justified, in my view, I also take a more inductive approach and estimate the model on a moving three-sexenio (i.e. 18-year) window, allowing coefficients to adjust. As we see below, these estimates support the view that the mid-1950s was a turning point in appointment practices.

The time period covered by the analysis (1940-2000) ${ }^{22}$ encompasses ten six-year presidential administrations (sexenios). I conduct the analysis at the sexenio (rather than year) level because the majority of appointments (56\%) occur in the first year of the administration, and in many years few or no appointments occur. Thus, the data structure resembles a repeated cross section rather than a panel; most individual elites drop out of the data after two periods (due to the 12-year rule used to determine candidacy for promotion). ${ }^{23}$ Given this data structure, I estimate logistic regression models of the odds of reaching the cabinet, conditional on meeting the criteria for data subsets. $^{24}$ In order to control for unobserved differences in the likelihood of appointment across periods, I include period fixed effects (not shown in models). Clustering standard errors at the period level might also help address temporal heterogeneity. However, with a small number of groups, clustering may be biased (Angrist and Pischke, 2008: 319-323). In practice, I find that clustered standard errors for several variables of interest are smaller than conventional estimates; therefore, I use the more conservative conventional standard errors. Finally, promotion to the cabinet is a rare event, suggesting that an adjusted logistic model such as that proposed by King and Zeng (2001) may be appropriate; however, because results from these two models are extremely similar, I rely on the familiar logistic regression model.

\footnotetext{
${ }^{22}$ I do not examine appointments in the 1935-1940 period because the analytical strategy infers candidacy from officials active in the preceding administration; the first period of data is therefore not available for analysis.

${ }^{23}$ Due to the complexity of career paths, some elites remain in the data for longer. For example, an elite who reaches the second tier and remains active in second tier positions for more than twelve years is retained in the data.

${ }^{24}$ Specifically, the data structure makes logistic regression a better choice than hazard analysis.
} 


\section{Clients, brokers and elite coalition formation in Mexico, 1940- 2000}

As argued above, the pyramidal patron-client and sponsorship models have both micro and structural implications; at the structural level, the pure patronage model implies that elite networks exhibit a pyramidal hierarchy. A first test of this model is whether the structure of the Mexican political elite is consistent with this expectation. To address this question, I begin by illustrating the Mexican elite network in figure 1, which depicts vertical (including only recruitment and sponsorship) and aggregate (including all vertical and horizontal ties) networks in 1958, at the beginning of the period of consolidated rule. ${ }^{25}$ (Diagrams for all ten periods are provided in the appendix). The vertical network represented in figure 1a does indeed appear highly hierarchical, suggesting a rigorous patron-client pyramid. However, after including horizontal ties (especially co-education ties, which as noted above account for a substantial proportion of the density of these networks) in figure 1b, the network structure is visually more ambiguous. Assessing network structure requires a more formal approach.

[Figure 1 about here.]

Table 4 assesses the network structure of the Mexican elite more systematically by presenting three measures which capture the extent to which the network approximates a pyramid or tree-like structure: efficiency, asymmetry and "lubness" (Krackhardt, 1994). ${ }^{26}$ A perfectly pyramidal structure would receive a score of one on each measure; scores below one reflect deviation from strict hierarchy. Table 4 shows that the vertical network is both highly asymmetric (indicating that recruitment is seldom reciprocated) and efficient (indicating a low level of transitivity). However, "lubness" is low in all periods: there is no "patron's patron" in the Mexican political elite. This implies that the vertical network consists of multiple, competing hierarchies, rather than a single rigorous pyramid. The full network specification has similar implications. Note that while hori-

\footnotetext{
${ }^{25}$ This figure is based on subset 1.

${ }^{26}$ I refer to Krackhard's "hierarchy" measure as asymmetry in order to avoid confusing specific and general meanings of hierarchy. "Lubness" refers to a Least Upper Bound (LUB), a node to which two other nodes are subordinate (i.e. a "patron's patron").
} 
zontal ties are symmetric by construction, the full network specification remains highly efficient, indicating that there are few transitive relationships and cycles in the network data. Thus, even though these horizontal ties are not based on information that permitted inference about the direction of ties, they are structurally fairly consistent with patron-client ties, lending credence to the interpretation of these ties as reflecting "quasi-patronage" relations. However, with the exception of one outlier period, "lubness" remains low in most of the ten periods covered by the analysis. ${ }^{27}$

[Table 4 about here.]

The key implication of these descriptive results is that the Mexican political elite consists of multiple patronage networks, rather than a single, pyramidal hierarchy. Elite network structure inferred from career histories is consistent with the description, cited above, of the Mexican elite as "a series of vertically and horizontally interlocking, roughly pyramidal, groups" (Centeno, 1997: 147). However, there is little support for the strictly hierarchical interpretation of the Mexican political elite as a pyramid with the president at the apex. This suggests that top-down centralization in the Mexican political elite was limited, and not likely to be a durable strategy of elite coalition formation. Because of the absence of a single power center or "patron's patron," there is little reason to think that informal elite networks in Mexico provided a durable mechanism for top-down control. Rather, in a competitive "sponsorship" system, there were multiple clusters of patron-client (and quasi-patronage) ties, creating a potent source of potential division.

A second important macro-level question concerns the group structure of the Mexican elite. Below, I report brokerage measures that incorporate group memberships inferred from the pattern of ties using the modularity maximization approach (Newman and Girvan, 2004). This method identifies clusters by maximizing within-group density and minimizing between-group density. Before presenting these results, it is important to confirm that this method produces a substantively informative classification of elites. Table 4 reports summary statistics; in all periods, modularity is positive, indicating nonrandom group structure, and falls within the typical .3-.7 range (Newman and Girvan, 2004), averaging .42. Chi-squared tests (not reported) reveal that in each period these

\footnotetext{
${ }^{27}$ The lubness measure for the full specification has a maximum of one because in one year (1994), there is a single node which can access all other connected nodes.
} 
group memberships are highly associated with alternative methods for classifying of elites, such as by educational institution attended or the primary policy area of their governing experience (e.g. economic, social, and other policy areas). This is not surprising, given that the networks are inferred from educational and career trajectories; these classifications synthesize this information to identify clusters of nodes that worked and studied together. Thus, the modularity approach yields a substantively meaningful classification of elites.

Turning to the determinants of elite coalition formation, I first model the odds of cabinet appointment as a function of variables which reflect skill and experience. The first columns of tables 5 and 6 report these models for the regime formation and consolidated rule periods, respectively. For the early period, only control two variables significantly influence the likelihood of appointment: party experience (positively) and electoral experience (negatively). ${ }^{28}$ However, the consolidated rule period shows a wider range of influences on appointment, suggesting a bureaucratization of appointment criteria. As expected, experience measured in years is negatively associated with appointment probability (reflecting candidates' aging out of eligibility for promotion). Career diversity and economic policy experience increase the likelihood of promotion, while regional experience has a negative impact on cabinet appointments, indicating that elites who spend their careers in regional governments are less likely to reach the cabinet, even when they achieve candidacy. Elites with advanced degrees are not more likely to reach the cabinet, though this coefficient is positive and significant in some models below. Electoral experience is also negatively associated with cabinet appointment during the consolidated rule period $(\mathrm{p}=.054),{ }^{29}$ but party experience does not lead to a significantly higher likelihood of cabinet appointment. Though statistically somewhat ambiguous ${ }^{30}$ a key difference between the periods appears to be the importance of participation in the formal party structure during the period of regime formation period, but not in the later period of

\footnotetext{
${ }^{28}$ Because this subset has lower statistical power, non-significant coefficients do not necessarily imply different patterns across periods; however, several coefficients have opposite signs in the two periods.

${ }^{29}$ This result lends additional credence to the claim that electoral experience is not an alternative route to the cabinet (and that the population of administrative officials examined here is represents the candidate pool for the cabinet). On the contrary, this implies that time taken from administrative positions in favor of elected positions in the congress or governorships reduces elites' chances of reaching the cabinet. In broader data subsets reported below, this coefficient remains negative, though it loses significance.

${ }^{30}$ In a pooled model, an interaction effect between the party experience variable and a dummy for the regime formation period is only significant in some data subsets and specifications.
} 
consolidated rule. These initial results imply a shift from an appointment logic dominated by party activism to a more bureaucratic and technocratic after the 1950s, an important transformation in the logic of of elite coalition formation. They are also consistent with a growing bureaucratization of the regime (though testing this claim is not the main goal of the paper).

[Table 5 about here.]

[Table 6 about here.]

The second and third columns of tables 5 and 6 present baseline network models of cabinet promotion incorporating patron-client ties and network size. In both periods, there is strong evidence confirming what observers of the Mexican political system have long argued: vertical patronage relations with the president significantly increase the likelihood of promotion to the cabinet. In contrast, horizontal ties to the president are robustly associated with cabinet appointment in the regime formation, but not consolidated rule periods. Indeed, coefficients for the latter period are negative, and the coefficient for two-step ties is statistically significant (though the significance level declines below .05 once degree effects are fully incorporated). ${ }^{31}$ As noted above, these ties are structurally consistent with a "quasi-patronage" interpretation. The result for the regime formation period is consistent with the historical literature on the Mexican elite; for example, Camp (1990: 92) notes that a substantial proportion (60\%) of the camarilla of President Miguel Áleman (1946-1952) consisted of his classmates from the National University (UNAM) law school. This suggests that horizontal relationships of trust based on co-education ties later became a resource in the highly asymmetric context of a President appointing his cabinet, consistent with an exchange of a position for support based on a prior, established relationship.

These results suggest that during the earlier period, presidents drew on a wider range of social relationships when forming their elite coalitions, including non-hierarchical career and educational ties. Though the interpretation must be tentative, this appears to imply a greater emphasis on personal connections in elite coalition formation (particularly given the relative paucity of other

\footnotetext{
${ }^{31}$ This weakly significant effect of two-step horizontal ties is difficult to interpret. Since the comparison group represents elites three or more steps away from the president in both horizontal and vertical networks, the negative coefficients suggest a preference for candidates distant in vertical networks over those distant in horizontal networks.
} 
determinants of cabinet appointment during this period). The fact that indirect (two-step) vertical ties are also associated (albeit at $\mathrm{p}=.054$ ) with cabinet appointments in the regime formation period, but not later, also lends some provisional support to this interpretation. Thus, while presidential patronage played a role in cabinet appointments in both periods, a wider range of patron-client (and quasi-patronage) ties formed the basis of elite coalitions. Patronage is also connected to party activism: presidential ties and other network resources moderate the party experience effect somewhat. These findings begin to suggest that during the still-unsettled period of regime formation, presidential strategies of coalition formation focused on centralization through recruiting loyal allies (and related party activism), while the basis of elite coalitions diversified over time.

This interpretation is further supported by the effects of network size on the likelihood of appointment. Column 3 of table 6 strongly supports a non-linear orthogonal polynomial specification of the relationship between degree and cabinet appointments in the consolidated rule period: the second-order term is statistically significant, and the non-linear model is preferred on AIC grounds. This relationship is illustrated in the first panel of figure 2. Network ties increase the likelihood of cabinet appointment up to about the mean number of ties; above the mean, however, the benefit of additional ties levels off and appears to decline. This non-linearity seems to reflect a ceiling effect: while promotion probability declines at high levels of the degree index, uncertainty around this estimate makes it difficult to interpret this effect as showing that elites with high levels of network resources are actually at a disadvantage for promotions.

\section{[Figure 2 about here.]}

Because total network size is an additive function of vertical in-degree (number of patrons), vertical out-degree (number of clients) and horizontal degree (number of peers), it is possible to disaggregate this measure in order to determine whether these results reflect the recruitment of elites with multiple patrons, multiple clients, or the more ambiguous horizontal ties. Appendix tables A1 and A2 report a detailed exploration of degree effects on cabinet appointment; models are summarized graphically for the consolidated rule period in figure $2 .{ }^{32}$ These results show that

\footnotetext{
${ }^{32}$ Results from subsets 2 and 3 are substantively similar.
} 
the relationship between network size and appointment is primarily driven by relationships with patrons, and secondarily and less clearly by peer or quasi-patronage ties. The effect of peer or "quasi-patronage" ties is weaker and more uncertain, but the form of the relationship implies a positive association, and adding horizontal relationships to vertical in-degree results in a tighter estimate. Overall, the evidence is clearly inconsistent with the hierarchical patronage model: elites with more patrons are more likely to reach the cabinet; while the non-linear relationship might suggest some discrimination against elites with an extremely high number of patrons, the more cautious interpretation is that this non-linear functional form represents a ceiling effect.

In contrast, the exploratory analysis reported in appendix table A1 confirms the implication of table 5: network resources other than direct ties to the president had a generally negative impact on the odds of cabinet appointment during the early period of regime formation. Disaggregating vertical and horizontal ties shows that the negative association of total degree with appointment is driven by an elite's count of patrons, rather than other tie types. Thus degree effects are generally positive in the period of consolidated rule, but negative in the regime formation period. In contrast to findings thus far, this result is more consistent with the pure patronage model, which implies that leaders are suspicious of elites with the appearance of "divided loyalties."

These results show a shift in the logic of elite patron-client relations from the regime formation to consolidated rule periods. In the early period, presidential patronage and party experience were the exclusive logic of coalition formation. Elite patronage networks were not strictly hierarchical - there was never a "patron among patrons," at least in the informal social structure of the elite - and presidents drew heavily on their peer networks to form their cabinets. However, they did adopt one key prediction of the pure patronage model: avoiding candidates who had served multiple patrons and therefore had divided loyalties. Though this negative effect of secondary patrons is not robust to inclusion of brokerage measures (as shown below), it is the best-fitting model of cabinet formation in the regime formation period. The predominance of direct patronage (and quasi-patronage) and party activism in this period is consistent with the view that coalition formation strategies were an outgrowth of elite competition in the convulsive post-revolutionary period, in which the most trustworthy elite coalition partners were close longstanding classmates 
and colleagues; elites with multiple patrons were less likely to achieve appointment, consistent with a penalty for divided loyalties. In contrast, as the regime consolidated, appointment patterns became regularized: the career ladder solidified and experience became more valuable, as shown above. Presidents continued to choose some of their former students and previous appointees to serve on the cabinet, but they ceased drawing on their broader peer networks. Patronage remained substantively important, but lost its role as the sole driving logic of elite coalition formation. This is emblematic of a growing tendency towards deferential political behavior, also reflected in the rise of brokerage appointments.

Table 6 provides strong evidence of this rise, showing that brokers were valuable coalition allies during the period of consolidated rule. Betweenness centrality, representative and gatekeeper measures all have a significant positive association with appointment to the cabinet. However, occupancy of coordinator positions - corresponding to within-group brokerage locations — does not lead to a higher likelihood of cabinet appointment. This is unsurprising: if brokers are valuable because of their contribution to resolution of intra-elite disputes and the signaling effect of selecting cabinet members with ambiguous affiliations, within-group coordinators are much less valuable than elites spanning groups or clusters in the elite network. In contrast, as reported in table 5, in the regime formation period no brokerage measure is statistically significant, and the sign on betweenness centrality is negative.

In the consolidated regime period, brokers have a substantively larger probability of cabinet appointment than non-brokers, defined as elites whose brokerage score takes its minimum value (which account for $25 \%$ of candidates). The strongest results are for gatekeeper and representative brokerage measures: elites one standard deviation above the mean of the "gatekeeper" distribution have a probability of cabinet appointment of 8-9\%, compared to $2 \%$ for non-brokers. Although the absolute probability of appointment remains relatively low (reflecting the highly competitive nature of these appointments), this is a four-fold increase in the probability of appointment. Overall, in this subset of the data, approximately $20 \%$ of cabinet members meet this definition of brokerage. Among these, a smaller subset amounting to about $8 \%$ of cabinet secretaries are "super-brokers" situated two standard deviations or higher above the mean of the distribution of these brokerage variables. 
The most clearly valuable group are gatekeepers, who have a nearly $12 \%$ appointment probability two standard deviations above the mean (a condition met by about $15 \%$ of secretaries) and $14 \%$ for those three standard deviations of the mean (met by about $8 \%$ of secretaries). Given the high level of competition for these positions and the low baseline chance of reaching the cabinet, these probabilities represent a substantial advantage in competition for cabinet appointments, indicating that brokers were valuable allies in elite coalitions.

Table 7 confirms these results by extending the analysis to broader subsets of the cabinet, reaching similar conclusions. The models include additional terms for reaching the second tier (that is, having reached the modal career path to the cabinet) and a non-linear experience effect. The latter term is included because, in addition to the "aging out" phenomenon observed on the modal career path, among the broader subset of candidates included in subsets 2 and 3, we also observe "aging in" to candidacy. The network determinants of promotion are corroborated in these models, which encompass up to $80 \%$ of observed secretaries (in subset 3). Direct vertical ties to the president, betweenness centrality, representative and gatekeeper positions are significantly associated with promotion in both of the two broader subsets (with the exception of gatekeeper positions in subset three). ${ }^{33}$

[Table 7 about here.]

To illustrate the positions captured by these brokerage measures, figure 3 presents a detail from the 1958 elite network shown in figure 1 above. The figure selects two groups (shaded grey and white) and illustrates the brokerage positions (shaded in black) of nodes with potential to mediate between them. These two brokers are Antonio Ortiz Mena (appointed Treasury Secretary in 1958) and Eduardo Bustamante Vasconcelos (appointed Secretary of Government Properties in the same year). (The third broker in this figure is the outgoing secretary of the Treasury, Ramón Beteta, who was not a candidate for appointment because he was an incumbent).

Broadly speaking, these brokers were intermediaries between two distinct clusters in the Mexican political elite of this period. The first cluster (white nodes in figure 3) includes many of the major

\footnotetext{
${ }^{33}$ In contrast to subset 1 , coordinator positions appear to be related to appointment in subsets 2 and 3 ( $\mathrm{p}=.054$ and .082, respectively); however, because these coefficients are substantively smaller, the evidence that coordinators were at an advantage for promotion is weak.
} 
political figures of the period since 1940s, including former Presidents Miguel Áleman (1946-1952) and Ruiz Cortines (1952-1958). This group's background is marked by electoral experience (67\% of members), party activism (40\%), and law degrees from the National University (53\%), historically a key source of recruitment of the political elite (Babb, 2001). Roughly speaking, this cluster represents the influential camarilla of Miguel Áleman, one of the defining political groups of the early PRI elite. In contrast, the distinguishing feature of the more diffuse gray-shaded group was economic policy experience: on average this group had spent half their career in economic policy positions. Ortiz Mena and Bustamente Vasconcelos were thus intermediaries between the "political" elite and the more "technocratic" administrators based in the powerful Treasury secretariat and its satellites.

Although it is difficult to know the precise details of intra-elite negotiations and exchanges, the structural positions occupied by these elites imply that they were in a position to span a potentially divisive gap. The backdrop for these particular appointments was an episode of competition over budget authority that threatened to become a major source of division, in which Ortiz Mena and Bustamante Vasconcelos were central players (Centeno, 1997; Schlefer, 2008). It is constructive to re-consider this episode of elite competition from the perspective of elite networks. Some scholars have interpreted the intra-elite jockeying for control as the incoming President's attempt to centralize control and discipline semi-autonomous bureaucrats (Centeno, 1997: 79); if this were the case, one would expect him to appoint personal allies to lead the difficult-to-control secretariats. Notably, however, the President did not appoint close allies to these key economic policy positions: neither Ortiz Mena nor Bustamante had a direct tie to President Lopez Mateos. Instead, he chose elites who were well connected both to the "politico" elite clustered around the past two presidents and to the economic policy technocrats. This suggests that, rather than asserting top-down control, avoiding competition and conflict between potential rivals within the elite was the guiding strategy of elite coalition formation. Indeed, participants' accounts such as that of Ortiz Mena (while potentially self-serving) emphasize that elite dialogue facilitated defusing the conflict, and 1958 was the beginning of a period often called the "Mexican miracle," known for the Treasury's ability to impose macroeconomic discipline. Thus, an episode of latent intra-elite conflict that has 
attracted the attention of previous scholars turned into a period of lasting cooperation. Although the historical record does not provide precise data on the exchanges and negotiations that enabled compromise, it is noteworthy that in the face of latent elite conflict, the President chose to fill a structural hole rather than favor loyal personal clients.

[Figure 3 about here.]

In contrast to the results for the consolidated rule period, table 8 shows that no brokerage measure has a significant positive association with appointment during the regime formation period. The evidence in favor of negative effects of brokerage in a fragmented context, as argued by Barnes et al. (2016), is weak at best: although coefficients are negative during this period, they are not significant and too confounded with network size to draw firm inferences. Appendix table A3 confirms the statistical difference between regime formation and consolidated rule periods: for all brokerage indicators significantly associated with cabinet appointment during the consolidated rule period (that is, betweenness, representative, and gatekeeper positions), interaction effects with a dummy variable representing the regime consolidated period are significant, indicating that the value of brokers was essentially zero in the earlier period. The best-fitting model (on AIC grounds) for the regime formation period remains model 2 in table 6; as argued above, this model provides evidence that contacts with patrons other than the president were negatively associated with appointment, suggesting that presidents avoided appointing elites with the appearance of divided loyalties to the cabinet.

[Table 8 about here.]

In order to test for additional variations fluctuations in the relationship between brokerage and appointment, I re-estimate model 4 in tables5 and 6 on a moving three-sexenio (18 year) window, as illustrated in figure 4. These results show that the relationship between brokerage positions and cabinet appointments remained highly stable in the post-1950s period. In particular, there is little evidence of a decline in brokerage appointments either before or after Cardenas' defection in the 1980s. The only sexenio in which brokerage appointments appear to decline to zero is 1976-82. However, it is difficult to rule out the possibility that this reflects statistical noise. Overall, these 
time-varying models reinforce the finding that the major shift in the role of brokerage in cabinet appointments occurred in the mid-1950s, and provide little evidence of further fluctations. As suggested above, this is consistent with both the hypotheses advanced above and the strengths of the dataset and analysis, which are best suited to capturing long-term trends.

\section{[Figure 4 about here.]}

To summarize, these results provide evidence of a transformation in the logic of elite coalition formation in Mexico before and after the consolidation of the one-party regime. Before the 1950s, cabinet promotions were dominated by the logic of party activism and presidential patronage, to the exclusion of other factors. Moreover, Presidents avoided appointing candidates with potentially divided loyalties, consistent with a fairly hierarchical patronage system. I interpret these appointment patterns as characteristic of elites whose approach to elite coalition formation was shaped by the elite infighting of the decades following the Mexican revolution: personal loyalty above all else. After the 1950s, the logic of appointments became more regularized. The timing of appointments was standardized; career diversity and economic policy experience gained value, and party activism lost significance. Net of these factors, elite patronage continued to play a role, with presidents selecting a subset of their coalition from direct, personal allies with which they shared prior connections. However, the patronage system became less hierarchical, with elites tied to more patrons (and perhaps "quasi-patrons") gaining an appointment advantage, consistent with the sponsorship model but not strict patronage hierarchy. Finally, elites occupying brokerage locations were preferred coalition partners during the period of consolidated rule lasting more than forty years, but not during the earlier period of regime formation.

\section{Conclusion}

By analytically isolating coalition formation as a moment of elite political behavior, this paper opens the black box of elite political action. It deserves emphasis once again that the determinants of cabinet promotion reflect leaders' strategies of elite coalition formation: the political ends the leader hopes to achieve by delegating part of his power to a group of subordinates. Strategy implies agency; 
rather than identify a law-like causal linkage, the analysis uncovers emergent patterns of behavior in the varying contexts of regime formation and consolidation. At the broadest level, the results show that in the Mexican case, coalition formation strategies shifted away from hierarchical patronagebased strategies towards a mixed approach that blended a less hierarchical patronage system with elite brokerage. Despite the overwhelming emphasis on patronage in closed but competitive political elites (an empirically common form of political regime), patronage proves to be insufficient though not absent - as a strategy of elite coalition formation in the long run. This result shows that studies of political elites in a variety of one-party and dominant-party regimes from China to sub-Saharan Africa, as well as Mexico and other Latin American countries, should consider a wider range of elite network dynamics beyond simple patronage.

From the standpoint of the political networks literature, it is important to underscore that the brokers analyzed in this paper are neither mere intermediaries in patron-client systems (vertical brokers) nor the dominant players forming elite coalitions themselves. For theories of political brokerage, there are several key implications of these results. First, at the most basic level, the findings extend the literature on political brokerage to a new context in terms of both regime (a closed but competitive elite) and political action (coalition formation). Second, the salience of political brokers is not limited to "factionalized" contexts as argued by Gould (1989). Rather, brokerage emerged as a salient force in elite coalition formation strategies only with the consolidation of the regime; as argued above, there is no evidence that factionalism increased in the Mexican political elite. This result is important not only insofar as it revises and extends previous theory about the conditional significance of brokerage, but because it enables us to peer further inside the black box of elite political action. The theoretical point is simple: Gould argued that brokers had limited scope to mediate exchanges in an elite devoid of gaps or 'synapses;' this assumes that the existence of such gaps is fixed ex ante, before the political game is played. In contrast, coalition formation is a part of the game. In this context, whether the elite is factionalized or not is potentially an ex post outcome of elite political action. In short, Gould's logic does not extend to dynamic settings in which the action of brokers can influence the level of elite conflict and cooperation.

Third, more generally, the context of elite coalition formation implies a strategic logic distinct 
from "robust action." Padgett and Ansell (1993) analyzed brokerage through the lens of elite centralization, arguing that decisive leaders emerge from strategic locations between factions that enable masterful, chess-like political gamesmanship. Padgett and Powell (2012) offers a similar account of the rise of Deng Xiaoping in China. In contrast, relative to patronage strategies the recruitment of brokers in elite coalition formation implies a level of decentralization. Rather than a strategy of top-down centralization, recruiting brokers implies a more deferential and inclusive strategy of elite coalition formation. These accounts are not contradictory, but orthogonal: the robust action perspective emphasizes the brokerage exercised by dominant leaders at the apex of the elite, while this account focuses on the brokerage exercised by the allies of these leaders. Nevertheless, a general implication is that both the impetus to centralize and the limits of centralization fall within the purview of a relational theory of political brokerage.

These findings also have implications for theories of political patron-client networks. Qualitative descriptions (e.g Centeno, 1997), quantitative studies (e.g Gould, 1996), and theoretical models (Martin, 2009; Montgomery, 2007) invoke to varying degrees a strict pyramidal model of patronage hierarchies. If this model is to be more than a metaphor, this hierarchical network structure must be detectable in actual network data. These results support the more fluid sponsorship model over the pyramidal patronage model and further suggest a transition in the logic of elite patronage, from one in which elites serving multiple patrons - and thus liable to be suspect of divided loyalties - were avoided in elite coalitions, to one in which broader network resources including multiple patrons improved elites' chances of appointment. This distinction suggests that a "single patron" rule did play a role in the regime's early period, reflecting competition and mutual suspicion in an elite still characterized by internal jockeying for lasting dominance.

Throughout this paper, I have emphasized the implications of these findings for closed but competitive political elites. However, processes of elite coalition formation are not unique to these political systems. Even in open multi-party systems, elites must build intra-party coalitions in order to assert political control and further their career ambitions. Inter-party electoral competition is no guarantee of intra-party democracy; informal processes among party bosses and other elites play the dominant role in candidate selection, shaping elites political futures. The results presented in 
this paper do not generalize to these settings, but they do suggest a research methodology and empirical problematic that deserves further research.

\section{References}

Abbott, Andrew. 2001. Time Matters: On Theory and Method. University of Chicago Press.

Angrist, Joshua D and Jörn-Steffen Pischke. 2008. Mostly harmless econometrics: An empiricist's companion. Princeton: Princeton University Press.

Arriola, L. R. 2009. "Patronage and Political Stability in Africa." Comparative Political Studies 42:1339-1362.

Babb, Sarah. 2001. Managing Mexico: Economists from Nationalism to Neoliberalism. Princeton: Princeton University Press.

Barnes, Michele, Kolter Kalberg, Minling Pan, and Ping Sun Leung. 2016. "When is brokerage negatively associated with economic benefits? Ethnic diversity, competition, and common-pool resources." Social Networks 45:55-65.

Bearman, Peter S. 1993. Relations Into Rhetorics: Local Elite Social Structure in Norfolk, England, 1540-1640. Rutgers University Press.

Bruggeman, Jeroen. 2013. Social Networks: An Introduction. London: Routledge.

Bruhn, Kathleen. 1997. Taking on Goliath: The Emergence of a New Left Party and the Struggle for Democracy in Mexico. University Park: The Pennsylvania State University Press.

Burt, Ronald. 1992. Structural Holes: The Social Structure of Competition. Cambridge: Cambridge University Press.

Burt, Ronald S. 2004. "Structural Holes and Good Ideas." American Journal of Sociology 110:349-399.

Burt, Ronald S. 2010. Neighbor Networks: Competitive Advantage Local and Personal. Oxford: Oxford University Press.

Burton, Michael, Richard Gunther, and John Higley. 1991. "Introduction: elite transformations and democratic regimes." In Elites and democratic consolidation in Latin America and Southern Europe, edited by John Higley and Richard Gunther, pp. 1-37. Cambridge: Cambridge University Press.

Burton, Michael G. and John Higley. 1987. "Elite Settlements." American Sociological Review $52: 295$.

Camp, Roderic Ai. 1976. "Education and Political Recruitment in Mexico: The Áleman Generation." Journal of Interamerican Studies and World Affairs 18:295-321. 
Camp, Roderic Ai. 1990. "Camarillas in Mexican Politics: The Case of the Salinas Cabinet." Mexican Studies 6:85-107.

Camp, Roderic Ai. 2010. The Metamorphosis of Leadership in a Democratic Mexico. Oxford: Oxford University Press.

Camp, Roderic Ai. 2011. Mexican Political Biographies, 1935-2009. Austin: University of Texas Press.

Carlos, Manuel L. and Bo Anderson. 1981. "Political Brokerage and Network Politics in Mexico: The Case of a Dominance System." In Networks, Exchange and Coercion: The Elementary Theory and its Applications, edited by David Willer and Bo Anderson, pp. 169-187. New York: Elsevier North Holland.

Carpenter, Daniel. 2001. The Forging of Bureaucratic Autonomy: Networks, Reputations and Policy Innovation in Executive Agencies, 1862-1928. Princeton: Princeton University Press.

Castañeda, Jorge G. 1999. La herencia: arqueología de la sucesión presidencial en México. Mexico City: Alfaguara.

Centeno, Miguel A. 1997. Democracy Within Reason: Technocratic Revolution in Mexico. University Park: The Pennsylvania State University Press.

Cosío Villegas, Daniel. 1975. La sucesión presidencial. Mexico City: Editorial J. Mortiz.

Curtis, Gerald L. 2013. The Logic of Japanese Politics: Leaders, Institutions, and the Limits of Change. Columbia University Press.

Eisenstadt, S. N. and Luis Roniger. 1984. Patrons, Clients and Friends: Interpersonal Relations and the Structure of Trust in Society. Cambridge University Press.

Evans, Peter. 1995. Embedded Autonomy: States and Industrial Transformation. Princeton: Princeton University Press.

Evans, Peter and James E Rauch. 1999. "Bureaucracy and Growth: A Cross-National Analysis of the Effects of "Weberian" State Structures on Economic Growth." American Sociological Review 64:748-765.

Faris, R. and D. Felmlee. 2011. "Status Struggles: Network Centrality and Gender Segregation in Same- and Cross-Gender Aggression." American Sociological Review 76:48-73.

Fernandez, Roberto M. and Roger V. Gould. 1994. "A Dilemma of State Power: Brokerage and Influence in the National Health Policy Domain." American Journal of Sociology 99:1455.

Freeman, Linton C. 1978. "Centrality in social networks: A conceptual clarification." Social Networks 1:215-239.

Gould, Roger V. 1989. "Power and Social Structure in Community Elites." Social Forces 68:531-552.

Gould, Roger V. 1996. "Patron-Client Ties, State Centralization, and the Whiskey Rebellion." American Journal of Sociology 102:400. 
Gould, Roger V. 2003. "Uses of Network Tools in Comparative Historical Research.” In Comparative Historial Analysis in the Social Sciences, edited by James Mahoney and Dietrich Rueschmeyer, pp. 241-269. Cambridge: Cambridge University Press.

Granovetter, Mark S. 1973. "The Strength of Weak Ties." American Journal of Sociology 78:1360-1380.

Greene, Kenneth F. 2007. Why Dominant Parties Lose: Mexico's Democratization in Comparative Perspective. Cambridge: Cambridge University Press.

Grindle, Marilee S. 1977. "Patrons and Clients in the Bureaucracy: Career Networks in Mexico." Latin American Research Review 12:37-66.

Grindle, Merilee S. 2012. Jobs for the Boys. Harvard University Press.

Hale, Henry E. 2010. "Eurasian polities as hybrid regimes: The case of Putin's Russia." Journal of Eurasian Studies 1:33-41.

Hamilton, Nora. 1982. The Limits of State Autonomy: Post-Revolutionary Mexico. Princeton: Princeton University Press.

Hernández Rodríguez, Rogelio. 1987. "Los hombres del presidente De la Madrid." Foro Internacional 28:5-38.

Hillmann, Henning. 2008a. "Localism and the Limits of Political Brokerage: Evidence from Revolutionary Vermont." American Journal of Sociology 114:287-331.

Hillmann, Henning. 2008b. "Mediation in Multiple Networks: Elite Mobilization before the English Civil War." American Sociological Review 73:426-454.

Hurtado, Miguel de la Madrid. 2013. Cambio de rumbo: Testimonio de una Presidencia, 1982-1988. Mexico City: Fondo de Cultura Economica.

Joseph, Gilbert Michael and Daniel Nugent. 1994. Everyday Forms of State Formation: Revolution and the Negotiation of Rule in Modern Mexico. Duke University Press.

Keller, Franziska Barbara. 2016. "Moving beyond factions: using social network analysis to uncover patronage networks among Chinese elites." Journal of East Asian Studies 16:17-41.

Kettering, Sharon. 1986. Patrons, Brokers, and Clients in Seventeenth-Century France. New York: Oxford University Press.

King, Gary and Langche Zeng. 2001. "Logistic Regression in Rare Events Data." Political Analysis 9:137-163.

Knight, Alan. 2014. "The End of the Mexican Revolution: From Cárdenas to Ávila Camacho." In Dictablanda: Politics, Work and Culture in Mexico, 1938-1968, edited by Paul Gillingham and Benjamin Smith, pp. 47-69. Durham: Duke University Press.

Krackhardt, David. 1990. "Assessing the Political Landscape: Structure, Cognition, and Power in Organizations." Administrative Science Quarterly 35:342-369. 
Krackhardt, D. 1994. "Graph theoretical dimensions of informal organizations." In Computational organization theory, edited by Kathleen M Carley and Michael J Prietula, pp. 89-111. L. Erlbaum Associates.

Krackhardt, David. 1999. "The ties that torture: Simmelian tie analysis in organizations." Research in the Sociology of Organizations 16:183-210.

Langston, Joy. 2006. "The Birth and Transformation of the Dedazo in Mexico." In Informal Institutions and Democracy: Lessons from Latin America, edited by Gretchen Helmke and Steven Levitsky, pp. 143-159. Baltimore: Johns Hopkins University Press.

Laumann, Edward O, Peter V Marsden, and Joseph Galaskiewicz. 1977. "Community-elite Influence Structures: Extension of a Network Approach." American Journal of Sociology 83:594-631.

Laumann, Edward O. and Franz Urban Pappi. 1973. "New Directions in the Study of Community Elites." American Sociological Review 38:212.

Levitsky, Steven and Lucan A. Way. 2010. Competitive Authoritarianism: Hybrid Regimes After the Cold War. Cambridge: Cambridge University Press.

Levitsky, Steven R. and Lucan a. Way. 2012. "Beyond Patronage: Violent Struggle, Ruling Party Cohesion, and Authoritarian Durability." Perspectives on Politics 10:869-889.

Lin, Nan. 2002. Social Capital: A Theory of Social Structure and Action. Cambridge: Cambridge University Press.

Magaloni, Beatriz. 2008. Voting for Autocracy: Hegemonic Party Survival and its Demise in Mexico. Cambridge University Press.

Marsden, Peter. 1982. "Brokerage Behavior in Restricted Exchange Networks." In Social Structure and Network Analysis, edited by Peter V Marsden and Nan Lin, pp. 201-218. Beverly Hills: Sage Publications.

Martin, John Levi. 2009. Social Structures. Princeton: Princeton University Press.

McAdam, Doug, Sidney Tarrow, and Charles Tilly. 2001. Dynamics of Contention. Cambridge University Press.

McLean, Paul D. 2011. "Patrimonialism, Elite Networks, and Reform in Late-Eighteenth-Century Poland." The ANNALS of the American Academy of Political and Social Science 636:88-110.

Middlebrook, Kevin J. 1988. "Dilemmas of Change in Mexican Politics." World Politics 41:120-141.

Middlebrook, Kevin J. 1995. The Paradox of Revolution: Labor, the State, and Authoritarianism in Mexico. Baltimore: Johns Hopkins University Press.

Montgomery, James D. 2007. "The structure of norms and relations in patronage systems." Social Networks 29:565-584. 
Newman, Mark E.J. and Michelle Girvan. 2004. "Finding and evaluating community structure in networks." Physical Review E 69:1-16.

Padgett, John F and Cristopher K Ansell. 1993. "Robust Action and the Rise of the Medici, 1400-1434." American Journal of Sociology 98:1259-1319.

Padgett, John F and Walter W Powell. 2012. The Emergence of Organizations and Markets. Princeton: Princeton University Press.

Podolny, Joel M and James N Baron. 1997. "Resources and Relationships: Social Networks and Mobility in the Workplace." American Sociological Review 62:673-693.

Portes, Alejandro and Lori Smith. 2012. Institutions Count: Their Role and Significance in Latin American Development. Berkeley: University of California Press.

Reyna, José Luis. 1985. "Las elecciones en el México institucionalizado, 1946-1976." In Las elecciones en México: evolución y perspectivas, edited by Pablo González Casanova, pp. 101-118. Mexico City: Siglo XXI.

Rubin, Jeffrey W. 1997. Decentering the Regime: Ethnicity, Radicalism, and Democracy in Juchitán, Mexico. Duke University Press.

Schlefer, Jonathan. 2008. Palace Politics: How the Ruling Party Brought Crisis to Mexico. Austin: University of Texas Press.

Scott, James C. 1972. "Patron-Client Politics and Political Change in Southeast Asia." The American Political Science Review 66:91-113.

Shih, Victor, Christopher Adolph, and Mingxing Liu. 2012. "Getting Ahead in the Communist Party: Explaining the Advancement of Central Committee Members in China." American Political Science Review 106:166-187.

Simmel, Georg. 1950. "The Triad.” In The Sociology of Georg Simmel, pp. 402-8. New York: Free Press.

Smith, Peter H. 1979. Labyrinths of Power: Political Recruitment in Twentieth-Century Mexico. Princeton: Princeton University Press.

Stovel, Katherine and Lynette Shaw. 2012. "Brokerage." Annual Review of Sociology 38:139-158.

Van de Walle, Nicolas. 2007. "Meet the new boss, same as the old boss? The evolution of political clientalism in Africa." In Patrons, Clients and Policies: Patterns of Democratic Accountability and Political Competition, edited by Herbert Kitschelt and Steven I. Wilkinson, pp. 50-67. Cambridge: Cambridge University Press.

Weldon, Jeffrey. 1997. "The Political Sources of Presidencialismo in Mexico." In Presidentialism and Democracy in Latin America, edited by Scott Mainwaring and Matthew Soberg Stugart, pp. 225-258. Cambridge: Cambridge University Press.

Willerton, John P. 1992. Patronage and Politics in the USSR. Cambridge: Cambridge University Press. 

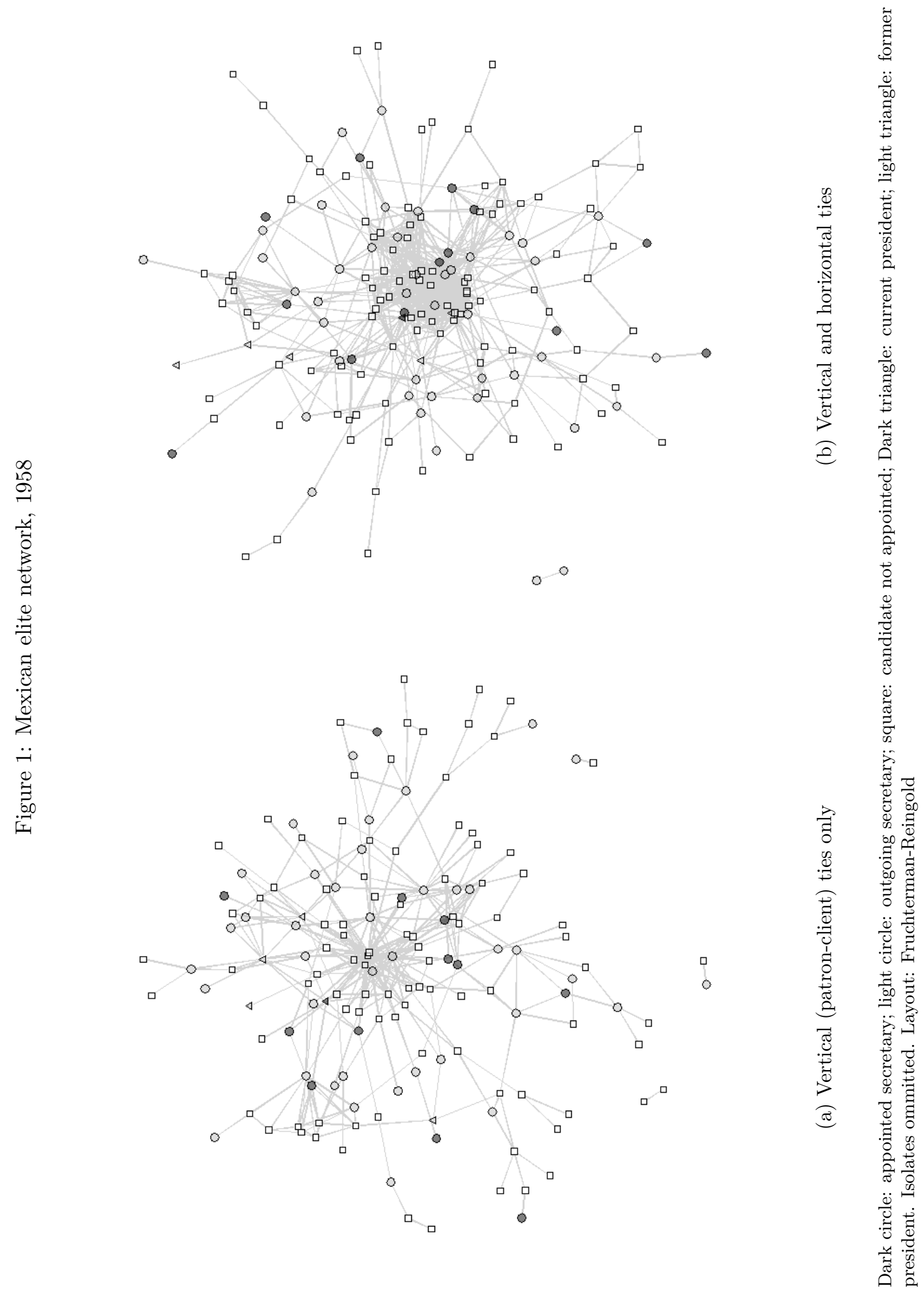
Figure 2: Network resources and cabinet appointments

Total degree

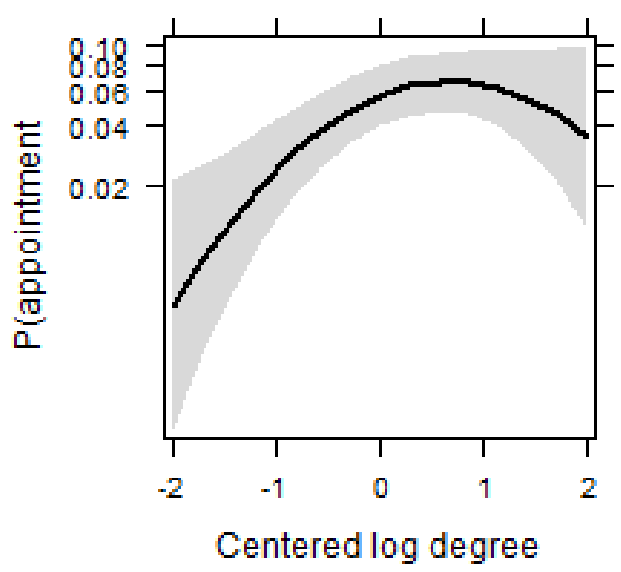

Vert. out-degree ( $\mathrm{N}$ clients)

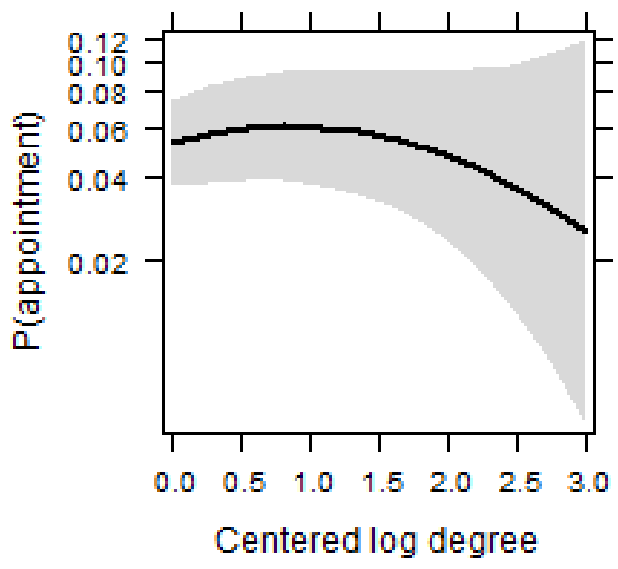

Vert. in-degree (N patrons)

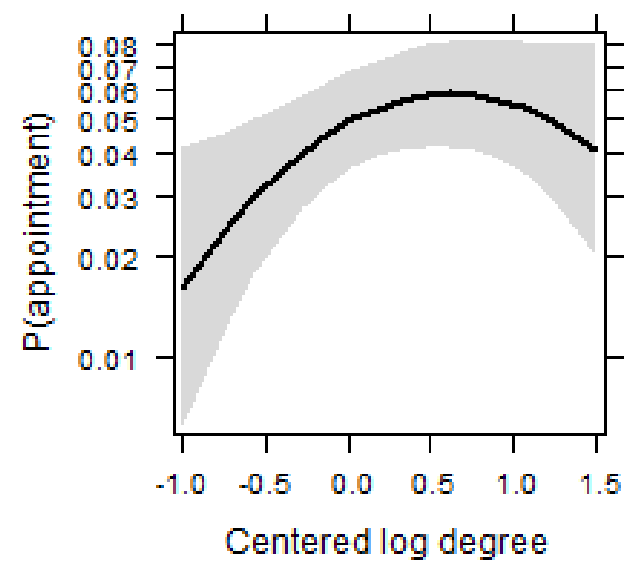

Horiz. total ( $\mathrm{N}$ peers)

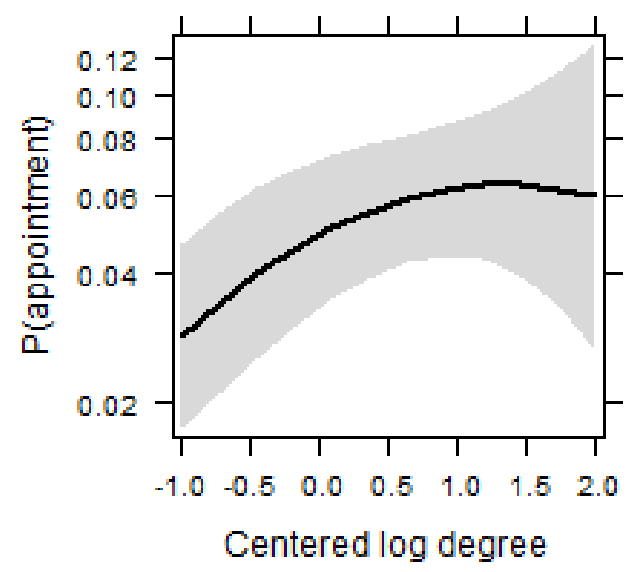


Figure 3: Detail: brokerage positions in 1958

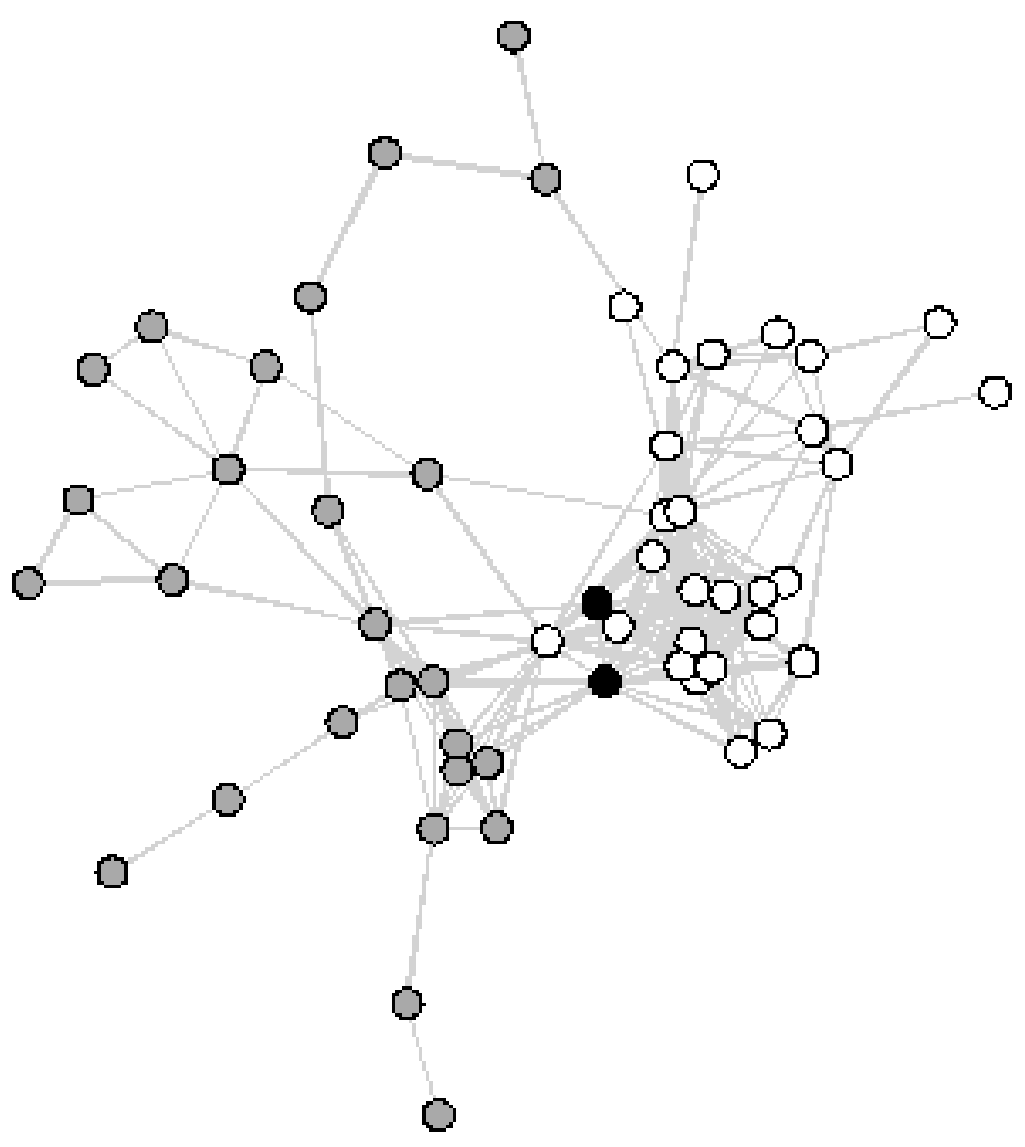


Figure 4: Time-varying coefficients

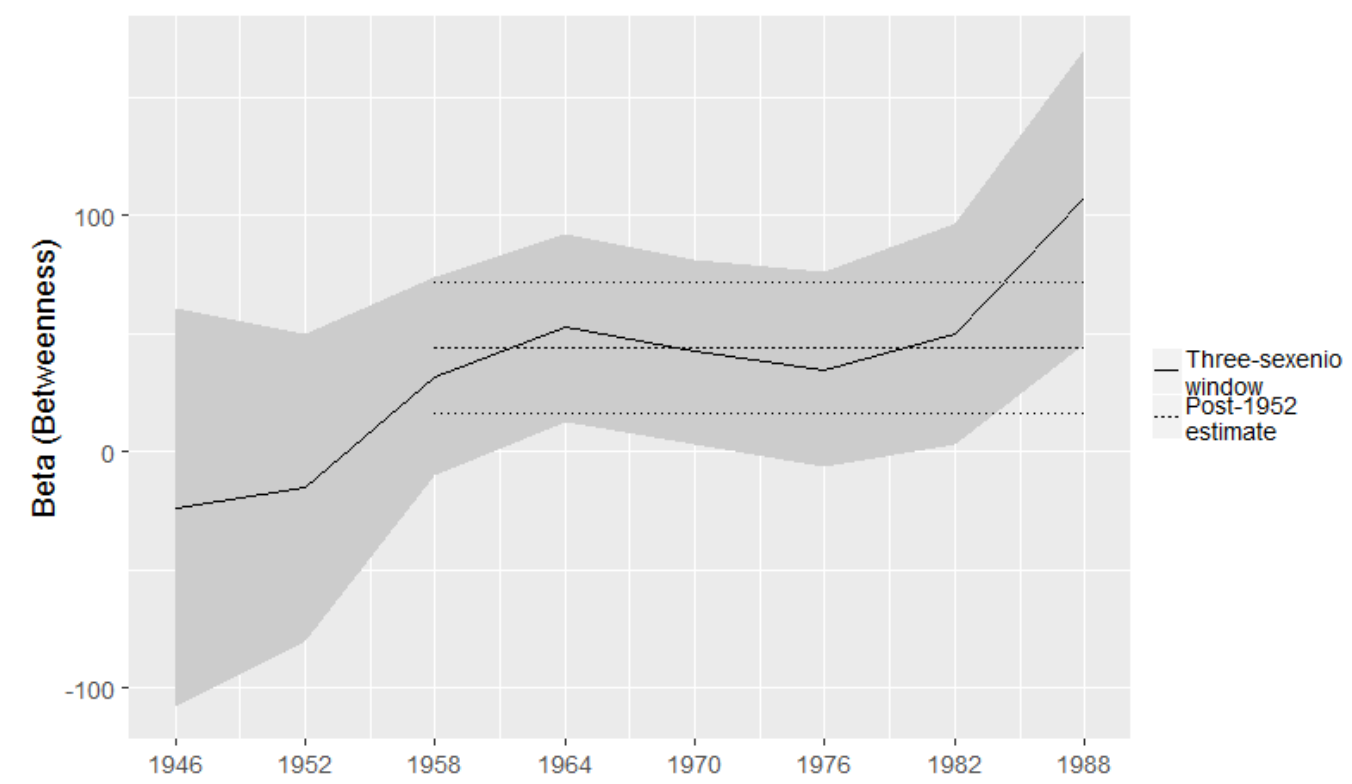


Table 1: Gateways to the cabinet,1940-2000

\begin{tabular}{clcccc}
\hline \hline Tier & Position & $\mathrm{N}$ & $\%$ & Cum. \% & \% Elec. Exp \\
\hline 2 & Assistant secretary & 67 & 0.37 & 0.37 & 0.15 \\
2 & Other 2nd tier & 35 & 0.19 & 0.56 & 0.49 \\
3 & Director General & 31 & 0.17 & 0.73 & 0.39 \\
4 & Director & 13 & 0.07 & 0.80 & 0.31 \\
$>4$ & Other & 37 & 0.20 & 1 & 0.51 \\
\hline
\end{tabular}

Table reports the highest non-elected position held by observed secretaries prior to cabinet appointment. "Other second tier" positions are oficial mayor, Attorney General, and director general of major autonomous state agencies. Percent electoral experience refers to the percentage of secretaries in each career group that also have electoral experience. 
Table 2: Definitions of network ties

\begin{tabular}{|c|c|c|}
\hline & Vertical & Horizontal \\
\hline Career & $\begin{array}{l}\text { Recruitment: as secretary or governor, } \\
i \text { recruits } j \text {. Recruitment is defined as } \\
j \text { changing positions in the organization } \\
\text { controlled by } j \text {. } \\
\text { Advisers and assistants are recruited } \\
\text { by the official specified in their job de- } \\
\text { scription (e.g. "advisor to the assistant } \\
\text { secretary of planning") }\end{array}$ & $\begin{array}{l}\text { Experience: } i \text { and } j \text { jointly hold posi- } \\
\text { tions in more than one organization in } \\
\text { different administrations; } \\
\text { Party: } i \text { and } j \text { jointly hold positions in } \\
\text { national or regional party organizations } \\
\text { in the same year }\end{array}$ \\
\hline Education & $\begin{array}{l}\text { Mentorship: } i \text { is professor and } j \text { a stu- } \\
\text { dent of the same subject in the same uni- } \\
\text { versity in the same year }\end{array}$ & $\begin{array}{l}\text { Co-education: } i \text { and } j \text { study the same } \\
\text { subject in the same university in the } \\
\text { same year; } \\
\text { Collegial: } i \text { and } j \text { teach the same sub- } \\
\text { ject in the same university in the same } \\
\text { year }\end{array}$ \\
\hline
\end{tabular}


Table 3: Density and connectivity

\begin{tabular}{lcccccc}
\hline \hline & \multicolumn{2}{c}{ Density } & \multicolumn{2}{c}{ Connectivity } & \multicolumn{2}{c}{ Isolates (\%) } \\
& Mean & SD & Mean & SD & Mean & SD \\
\hline Recruitment & 0.006 & 0.001 & 0.626 & 0.120 & 0.168 & 0.053 \\
Mentorship & 0.007 & 0.002 & 0.171 & 0.105 & 0.542 & 0.150 \\
Experience & 0.003 & 0.002 & 0.053 & 0.094 & 0.747 & 0.191 \\
Party & 0.001 & 0.001 & 0.021 & 0.027 & 0.855 & 0.083 \\
Co-education & 0.021 & 0.006 & 0.136 & 0.043 & 0.429 & 0.092 \\
Collegial & 0.005 & 0.002 & 0.014 & 0.011 & 0.800 & 0.057 \\
All ties & 0.041 & 0.007 & 0.872 & 0.058 & 0.054 & 0.037 \\
\hline
\end{tabular}

Table reports means and standard deviations over ten periods. 
Table 4: Descriptive network statistics: Hierarchy and group structure

\begin{tabular}{lcccc}
\hline \hline Statistic & Mean & St. Dev. & Min & Max \\
\hline N (network) & 225.300 & 80.229 & 122 & 348 \\
& Hierarchy: & Vertical ties & only \\
Efficiency & 0.989 & 0.002 & 0.986 & 0.993 \\
Asymmetry & 0.877 & 0.076 & 0.780 & 0.964 \\
Lubness & 0.136 & 0.055 & 0.064 & 0.215 \\
\multicolumn{5}{c}{ Hierarchy: } \\
Efficiency & 0.958 & 0.008 & 0.946 & 0.976 \\
Asymmetry & 0.357 & 0.142 & 0.164 & 0.618 \\
Lubness & 0.213 & 0.294 & 0.013 & 1.000 \\
N groups & 8.800 & 0.919 & 7 & 10 \\
Min. group size & 5.900 & 3.695 & 2 & 11 \\
Max. group size & 63.000 & 33.277 & 21 & 117 \\
Mean group size & 26.454 & 11.932 & 13.556 & 49.714 \\
Modularity & 0.424 & 0.064 & 0.334 & 0.541 \\
\hline
\end{tabular}




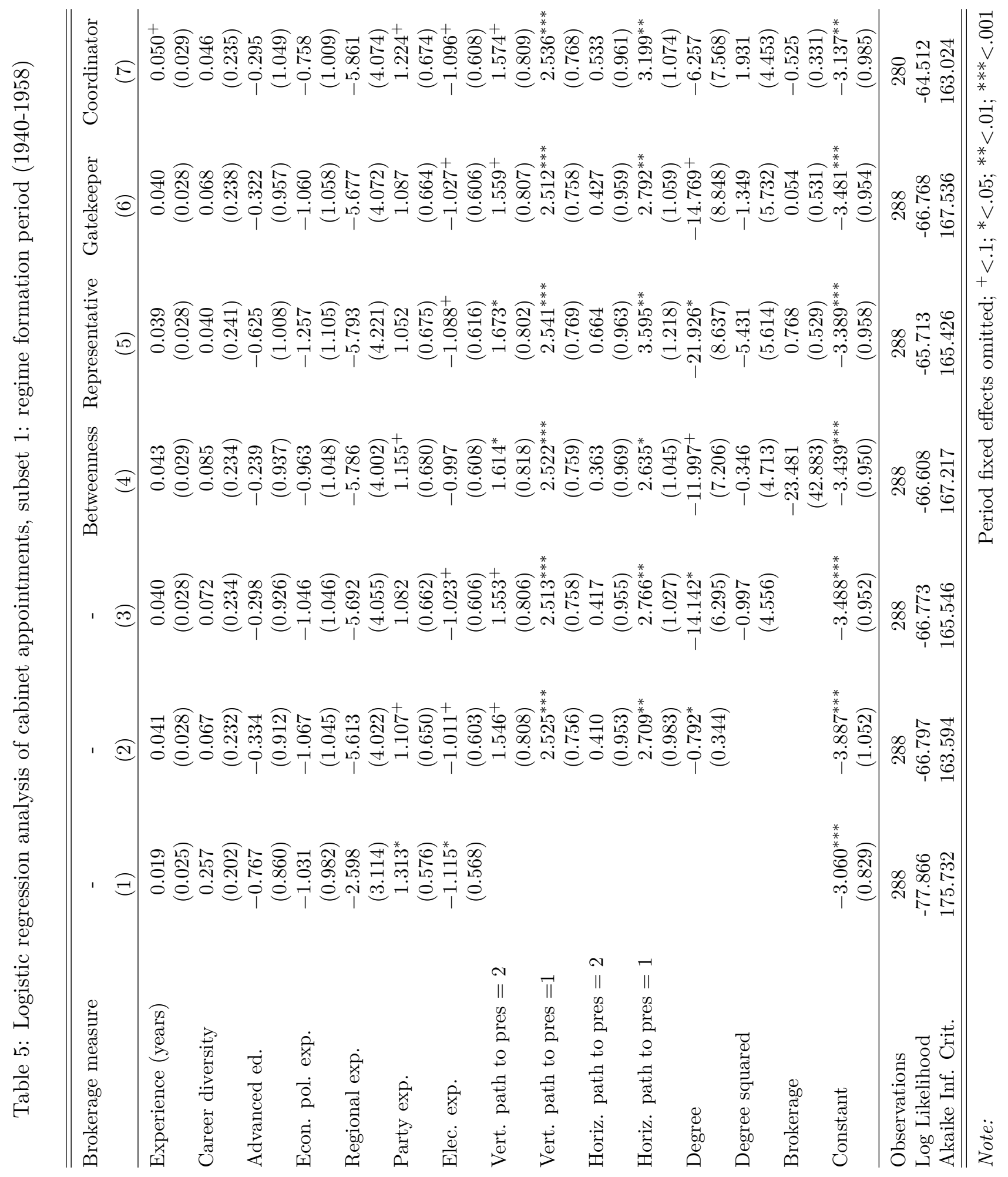




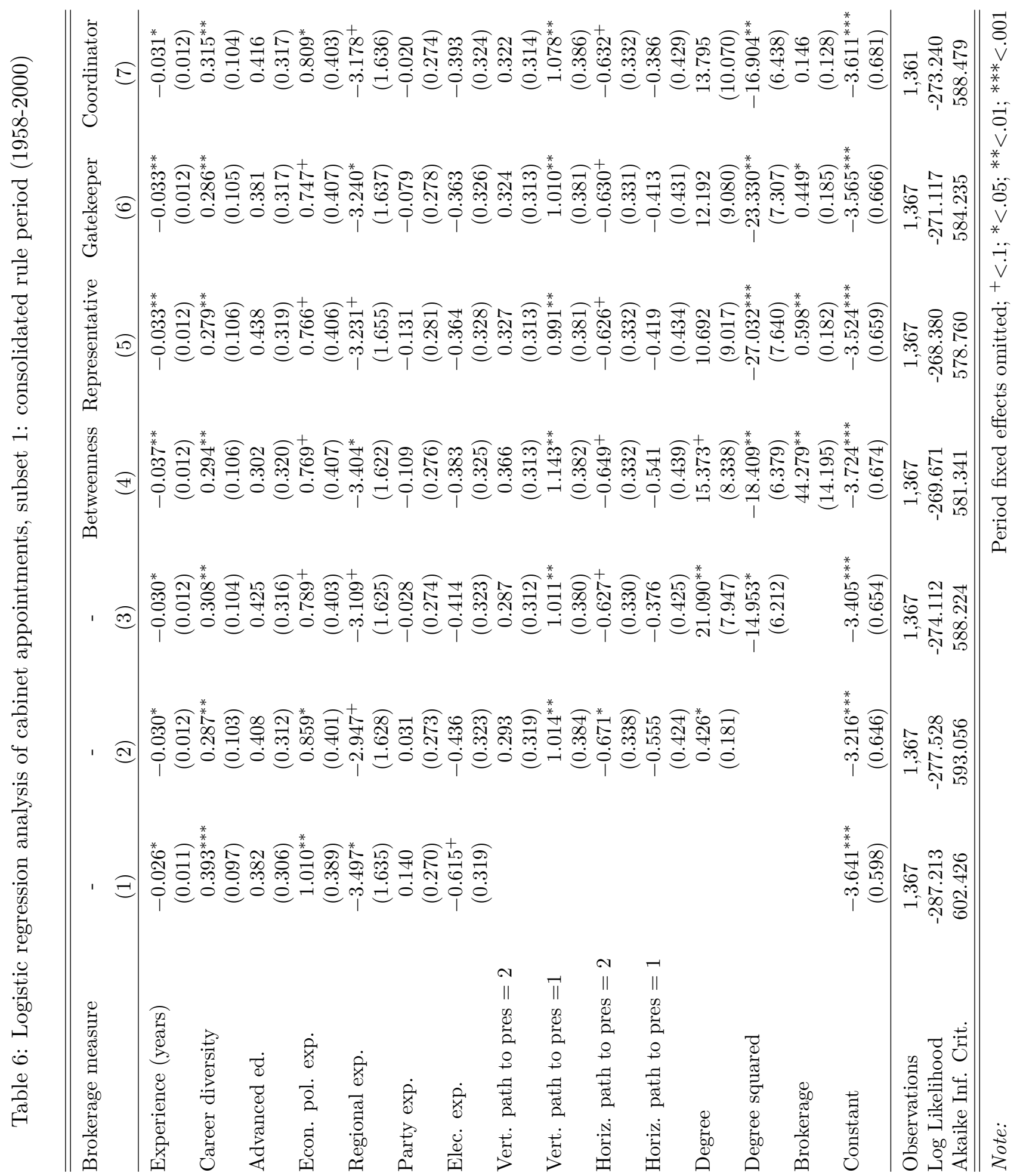




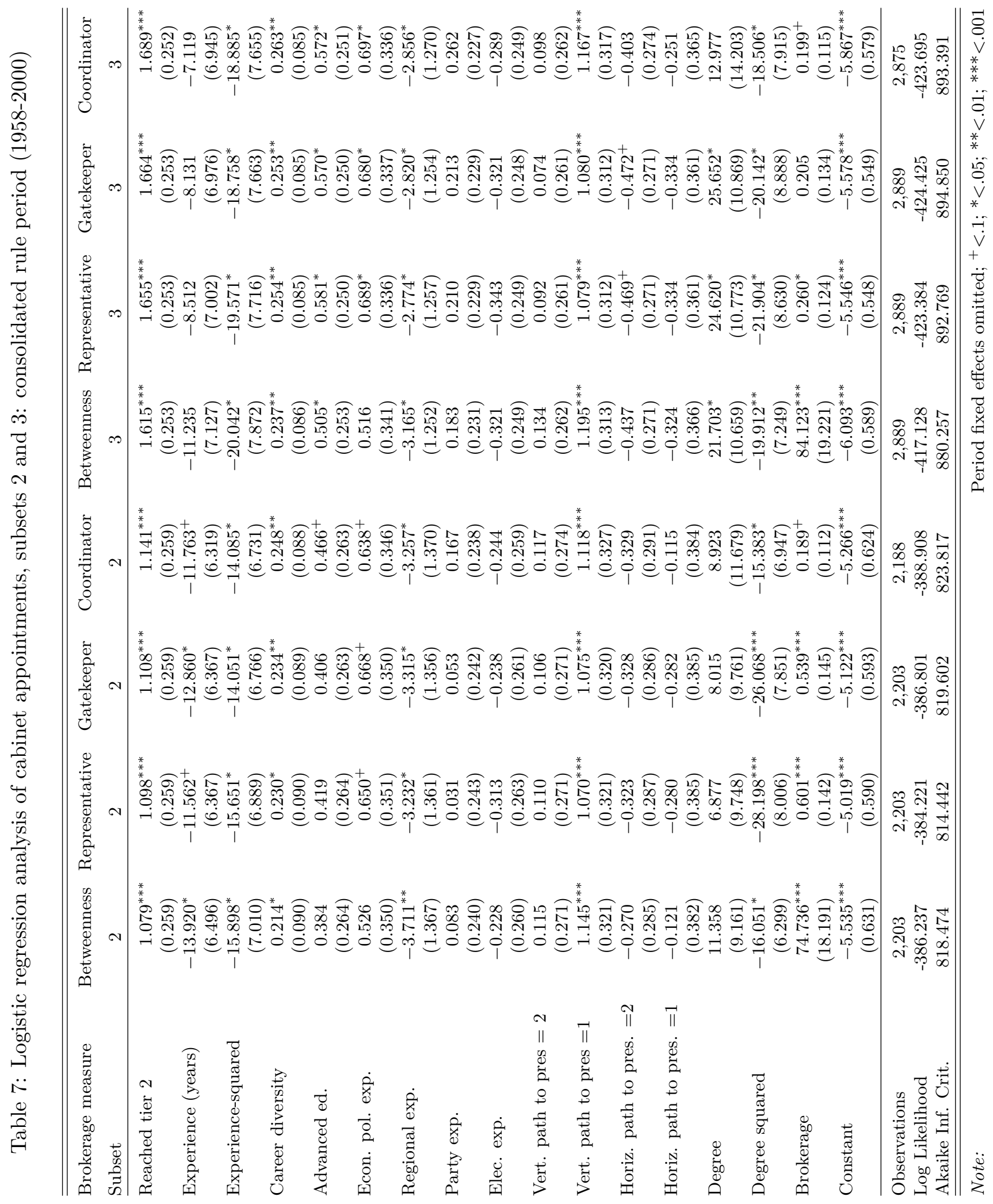




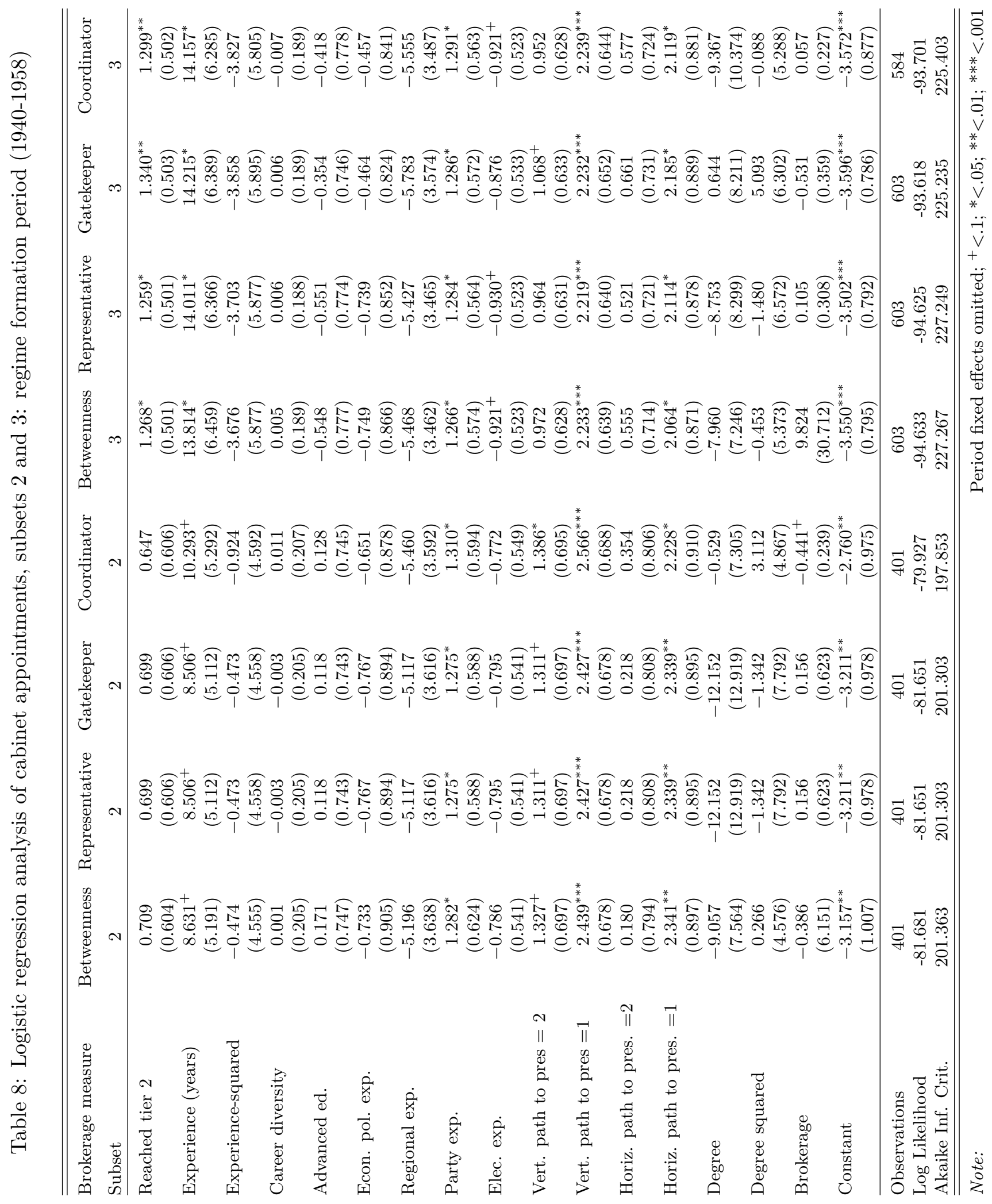

